\title{
Parasites, pathogens, and pests of honeybees in Asia
}

\author{
Panuwan Chantawannakul ${ }^{1}$, Lilia I. de GuZman ${ }^{2}$, Jilian Li $^{3}$, Geoffrey R. Williams ${ }^{4,5}$ \\ ${ }^{1}$ Bee Protection Laboratory (BeeP), Department of Biology, Faculty of Science, Chiang Mai University, Chiang Mai \\ 50200, Thailand \\ ${ }^{2}$ Honey Bee Breeding, Genetics and Physiology Laboratory, USDA-ARS, Baton Rouge, LA 70820, USA \\ ${ }^{3}$ Key Laboratory of Pollinating Insect Biology of the Ministry of Agriculture, Institute of Apicultural Research, Chinese \\ Academy of Agricultural Sciences, Beijing 100093, China \\ ${ }^{4}$ Institute of Bee Health, Vetsuisse Faculty, University of Bern, 3003, Bern, Switzerland \\ ${ }^{5}$ Agroscope, Swiss Bee Research Centre, 3003, Bern, Switzerland
}

Received 20 May 2015 - Revised 7 October 2015 - Accepted 26 October 2015

\begin{abstract}
Asia is home to at least nine honeybee species, including the introduced Apis mellifera. In addition to A. mellifera and Apis cerana being widely employed for commercial beekeeping, the remaining nonmanaged species also have important ecological and economic roles on the continent. Species distributions of most honeybee species overlap in Southeast Asia. This promotes the potential for interspecific transmission of pests and parasites and their spread to other parts of the world by human translocation. The decline of honeybee populations is of great concern around the world, including in Asia. The global colony losses of A. mellifera are believed to be caused, in part, by parasites, pathogens, and pests originating from Asia, such as the mite Varroa destructor, the microsporidian Nosema ceranae, and some bee viruses. This review discusses important pests, pathogens, and parasites in both the introduced A. mellifera and native honeybees in Asia to provide an overall picture of honeybee health in the region and future threats to the apiculture industry.
\end{abstract}

\section{Asia / bee virus / Tropilaelaps / Asian bee mites / honeybees / bee diseases}

\section{INTRODUCTION}

The natural world is ripe with examples of species population dynamics driven by biotic environmental pressures such as parasites, predators, and pests. Honeybees (Apis spp.) are no exception (Ellis and Munn 2005). In recent years, both wild and managed honeybees have experienced dramatic reductions in numbers in various regions of the world (Neumann and Carreck 2010), which has led to a flurry of research into explanations for these observations. The vast majority of these efforts have focused on the western honeybee

Corresponding author: P. Chantawannakul, panuwan@gmail.com

Manuscript editor: Marina Meixner
(Apis mellifera), which is unquestionably the single most globally ubiquitous and economically important honeybee species (Crane 1999). The general consensus is that reductions in A. mellifera colony numbers are primarily the consequences of multiple concomitant environmental pressures, of which parasites, pathogens, and pests play an important role (e.g., van Engelsdorp and Meixner 2010; Williams et al. 2010; Neumann and Carreck 2010). Relative to A. mellifera, investigations into the health of other honeybee species have taken a backseat, despite their importance to economic and social systems around the world (Crane 1999).

In this review, we focus on parasites, pathogens, and pests of honeybees in Asia. The region hosts multiple species of native honeybees, as well as the introduced $A$. mellifera. Despite the 
importance of these species as a source of bee products and pollination services (Oldroyd and Wongsiri 2006; Sanpa et al. 2015; Pattamayutanon et al. 2015), the health of native Asian honeybees has been relatively less studied compared to that of A. mellifera. Furthermore, comparative insights into parasites and pests of $A$. mellifera with native species in Asia provides powerful insights into parasite-host responses among these organisms. This is particularly important because several devastating parasites have host-jumped from native Asian honeybees to A. mellifera to become of global concern (Rosenkranz et al. 2010; Fries 2010). First, we introduce honeybee species diversity in the region as well as the interactions of these species with humans. We then review parasite, pathogen, and pest interactions with honeybees in Asia and conclude by providing directions for further investigations that would promote honeybee health in both Asia and abroad.

\section{APIS SPECIES DIVERSITY}

Asia hosts at least eight native honeybee species, with diversity highest in the tropics (Crane 1999). Multicomb-making cavity-nesting species, Apis cerana, Apis koschevnikovi, Apis nigrocincta, and Apis nuluensis, are particularly ubiquitous as a group and are classified as medium-sized bees (Ruttner 1988; Otis 1996; Tingek et al. 1996; Hepburn et al. 2001; Radloff et al. 2005a, b; Hepburn and Hepburn 2006; Takahashi et al. 2007; Tan et al. 2008; Radloff et al. 2010). Residing in protective cavities such as tree hollows, they are also wellknown to nest in human-made structures throughout the region (Oldroyd and Wongsiri 2006). Single comb-making open-air-nesting honeybees include the dwarf (Apis florea and Apis andreniformis) and giant (Apis dorsata and Apis laboriosa) honeybees (Sakagami et al. 1980; Otis 1996; Oldroyd and Wongsiri 2006; Hepburn and Radloff 2011). This group is limited to subtropical and tropical areas likely due to inherent vulnerability to the elements as a result of their open-nesting habits (Hepburn et al. 2005; Hepburn and Hepburn 2005; Oldroyd and Wongsiri 2006). These species can be found nesting on branches, cliff faces, and even under outcroppings of large urban structures (Crane 2003). Most recently, two new species, Apis indica in southern India and Apis breviligula in the Philippines, have been proposed (Lo et al. 2010). They were previously included with $A$. cerana and $A$. dorsata, respectively. In addition to native species, the introduced $A$. mellifera is widespread throughout the region (Wongsiri and Tangkanasing 1987; Crane 1999; Oldroyd and Wongsiri 2006).

\section{INTERACTIONS WITH HUMANS}

Asians have been associated with honeybees for thousands of years for food, medicinal products, and trade (Crane 1999). Opportunistic honeybee hunting preceded ownership of wild nests by individuals or communities (Oldroyd and Wongsiri 2006). The earliest evidence of annual claims to A. dorsata nests occur on rock faces (e.g., China between 265 and 290) (Crane 1999). Managing honeybees in hives first developed using A. cerana, whereby hives were fashioned using hollow logs, clay pots, or straw baskets. In western Asian countries like Pakistan and Afghanistan, this management technique occurred as early as 300 BC. In the east, hive beekeeping began in China circa 200. Adoption of beekeeping in other countries was sporadic in history, with Malaysia being one of the last countries to adopt native honeybee hive beekeeping in 1936 (Crane 1999). More recently, large-scale commercial hive beekeeping using $A$. cerana has been developed in temperate areas of China and India (Figure 1a, b). The A. cerana subspecies native to these areas are more profitable because they are less likely to abscond than other subspecies found in subtropical and tropical regions (Oldroyd and Wongsiri 2006; Hepburn and Radloff 2011). Nevertheless, due to its relatively greater potential for profitability compared to A. cerana, A. mellifera was widely imported from Europe, North America, and Oceania starting first in Russia, east of the Urals in the late 1700s, followed by Japan, India, and Indonesia in the late 1800 s. By the 1980 s, nearly every country in Asia accommodated the introduced A. mellifera (Crane 1999; Wu et al. 2006; Arai et al. 2012; Sanpa and Chantawannakul 2009). Asia currently accommodates the largest number of managed $A$. mellifera honeybee colonies in the world (FAO 2014). Organized surveys of A. mellifera populations in Asia report lower losses 

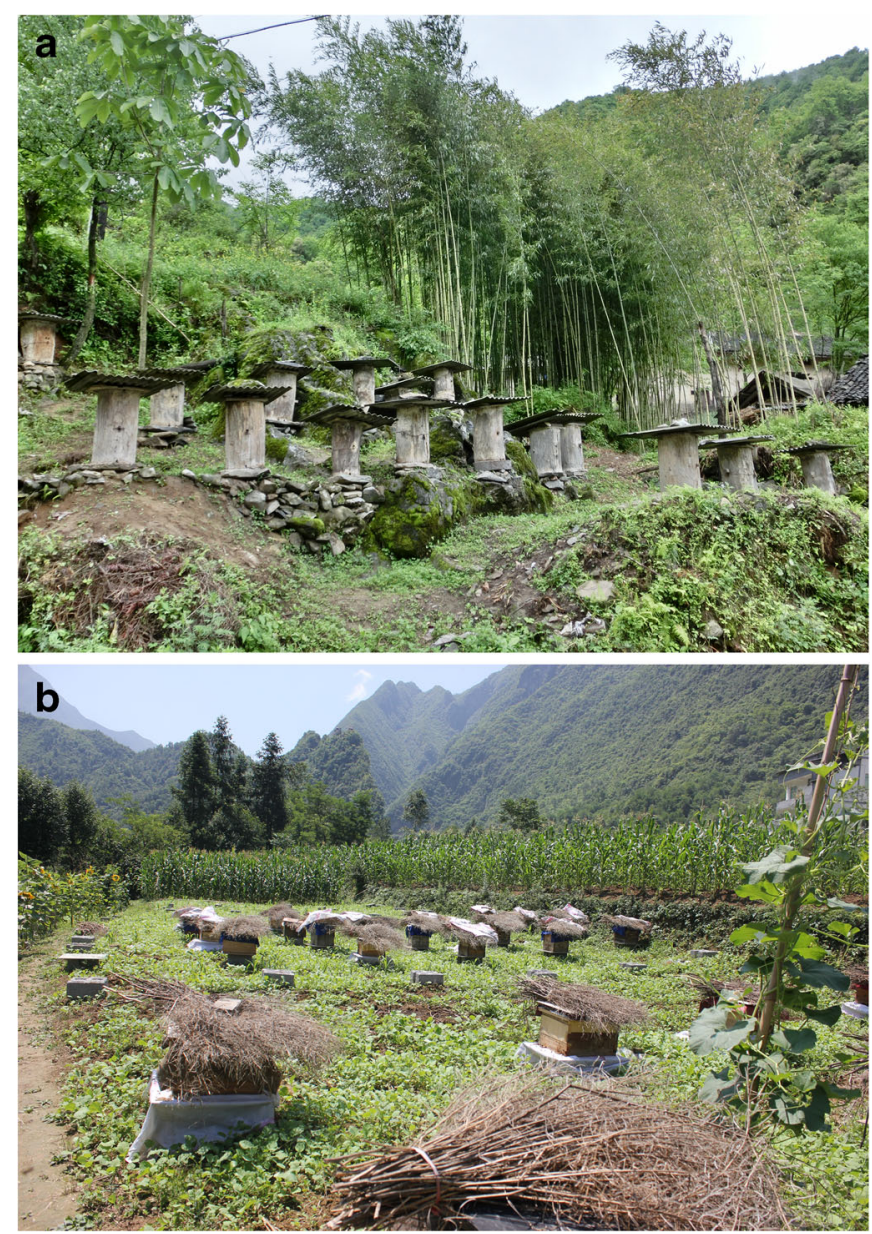

Figure 1. Apis cerana beekeeping in China. a Traditional hive (Hubei). b Modern box (Chongqing).

of managed colonies compared to Europe and North America (van der Zee et al. 2012). However, few work has focused on populations of native species, particularly because their migratory nature makes their study difficult. Anecdotal reports suggest $A$. cerana in China is under severe pressure from habitat and forage plant losses, displacement by the introduced $A$. mellifera, as well as interspecific transfer of pathogens and parasites (Yang 2005; He and Liu 2011; Li et al. 2012).

\section{HEALTH STRESSORS}

\subsection{Mites}

Asian honeybees are indigenous hosts of several species of parasitic mites. The sympatric existence of different species of honeybees and their associated parasitic mites in Asia potentially promotes the exchange of parasites among them, as well as concurrent infestations by multiple mite species at the colony or individual levels (Anderson 1994; Anderson and Trueman 2000; Buawangpong et al. 2015).

\subsubsection{Varroa spp.}

Within the genus Varroa, four mite species are described, Varroa jacobsoni (Oudemans 1904), Varroa underwoodi (Delfinado-Baker and Aggarwal 1987), Varroa rindereri (de Guzman and Delfinado-Baker 1996), and Varroa destructor (Anderson and Trueman 2000), all of 
which are known parasites of honeybees. First identified was $V$. jacobsoni parasitizing $A$. cerana in Java (Oudemans 1904). However, subsequent investigations in the region described additional species. $V$. underwoodi and $V$. rindereri were observed parasitizing $A$. cerana in Nepal and A. koschevnikovi in Borneo, respectively (Delfinado-Baker and Aggarwal 1987; de Guzman and Delfinado-Baker 1996). Reevaluation of $V$. jacobsoni revealed an additional species, $V$. destructor, infecting A. mellifera (Anderson and Trueman 2000). This redescription sent shock waves throughout Asia and abroad, as it became apparent that $V$. destructor, rather than $V$. jacobsoni, was the most prevalent Varroa mite parasitizing honeybees around the world. Varroa species nearly ubiquitously parasitize honeybees throughout Asia (Figure 2).

All species successfully parasitize cavitynesting honeybees. $V$. jacobsoni infests five honeybee species, including $A$. cerana, A. koschevnikovi, A. mellifera, A. nigrocincta, and A. nuluensis (Woyke et al. 1987a; Delfinado-Baker et al. 1989; Koeniger et al. 2002; Otis and Kralj 2001; de Guzman et al. 1996). In contrast, $V$. destructor has only been recorded in A. cerana and $A$. mellifera colonies (Anderson and Trueman 2000). V. underwoodi is restricted to $A$. cerana, $A$. nigrocincta, and A. nuluensis. Unlike its congeners, $V$. rindereri appears to be a species-specific parasite. It was found successfully infesting $A$. koschevnikovi, but was collected from debris of $A$. dorsata in Borneo along with $V$. jacobsoni (Koeniger et al. 2002).

The general morphology and chaetotaxy of the four Varroa species are similar. However, several characters such as body size (Table I) and shape, peritreme size, and length and number of marginal setae can be used to distinguish them. A wide genetic variation within and between $V$. jacobsoni and $V$. destructor populations exists in Asia and may play an important role in the pathogenicity of these parasites. Currently, 24 haplogroups, 15 for $V$. jacobsoni and 9 for V. destructor, are recognized (de Guzman and Rinderer 1998, 1999; de Guzman et al. 1997, 1998, 1999; Anderson and Trueman 2000; Fuchs et al. 2000; Zhou et al. 2004; Solignac et al. 2005; Warrit et al. 2006; Navajas et al. 2010), with the
Korean (K) and Japanese (J) haplotypes of $V$. destructor being the most successful parasites of A. mellifera (Rosenkranz et al. 2010). Of these, the $\mathrm{K}$ haplotype is competitively superior to $\mathrm{J}$ and represents the most pathogenic Varroa mite haplotype in Asia and abroad. Virulent parasites are generally more competitive than less virulent ones and may possibly displace them (Navajas et al. 2010). Failure to detect J haplotype mites in Thailand that were reported earlier (de Guzman and Rinderer 1999; Anderson and Trueman 2000; Navajas et al. 2010) may be a result of such a displacement event and not an erroneous finding as suggested by Warrit et al. (2006). Recent genetic analysis of Varroa mites in Asia revealed new invasions and hybridization between haplogroups (Navajas et al. 2010). The virulence of hybrid mites to honeybees has yet to be established.

In the Philippines, the Papua New Guinea (=Java) $V$. jacobsoni haplotype parasitizes $A$. cerana (de Guzman and Rinderer 1999), and three unresolved $V$. destructor haplotypes are known to reproduce in $A$. cerana drone brood (Anderson 2004). In $A$. mellifera and A. cerana, $V$. jacobsoni reproduces in drone brood only (Anderson 1994; Anderson and Sukarsih 1996; Anderson and Fuchs 1998), whereas reproduction of $V$. destructor in A. cerana is likely dependent on their haplotype or strain of the host bees (de Jong 1988). Inability of $V$. jacobsoni to reproduce in worker brood of A. cerana and A. mellifera has most likely limited its distribution and impact as drone brood is seasonally produced and relatively less crucial to overall colony functioning (de Guzman and Rinderer 1999). Variations in mite infestation or reproduction may be attributed to the combined effects of bee behavior, species, and haplogroup of mites. While grooming behavior removes mites from adult bees (Rinderer et al. 2010), hygienic behavior disrupts mite reproductive output when mites and infested developing bees are removed from brood cells (Kirrane et al. 2011). A. cerana is particularly well known for such behaviors (Peng et al. 1987a, b).

Although A. cerana is the indigenous host of $V$. jacobsoni and $V$. destructor, much of the life histories of the two are based on data using A. mellifera as the host. No biological 


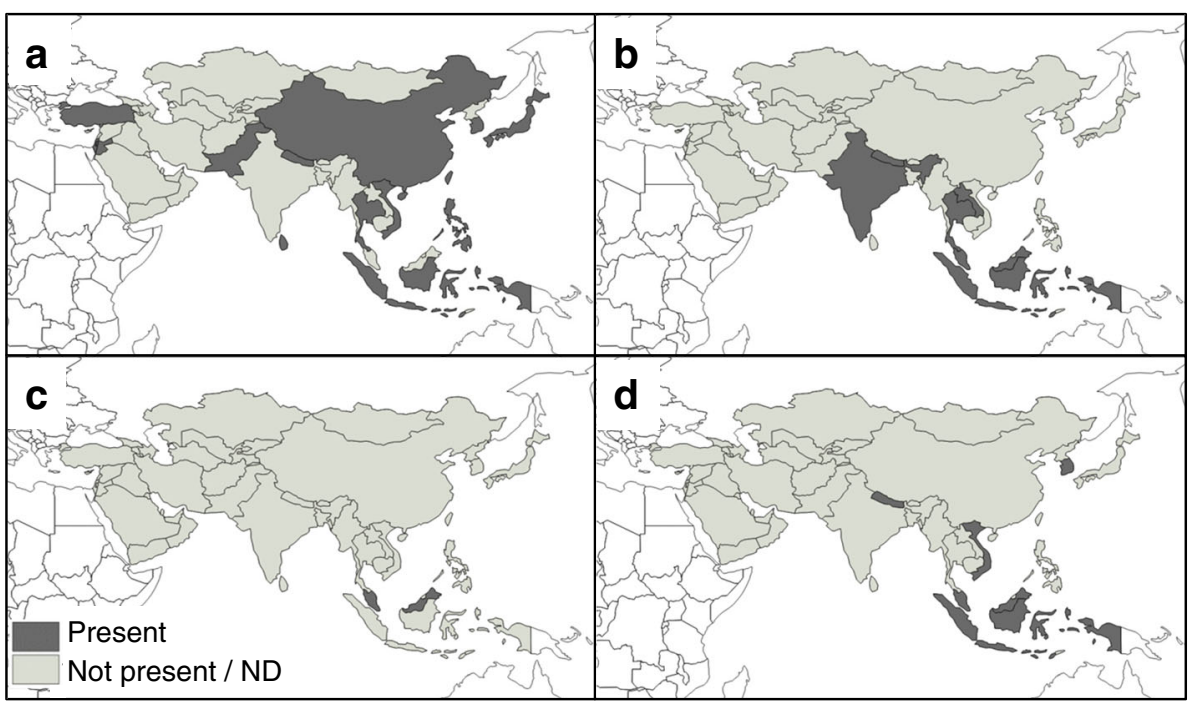

Figure 2. Distribution map of Varroa spp. in Asia. a Varroa destructor, b Varroa jacobsoni, c Varroa rindereri, and d Varroa underwoodi. Dark gray indicates Asian countries where the parasite has been detected in at least one honeybee species; light gray indicates Asian countries where the parasite has not been detected or no data (ND) are available.

observations are available for either $V$. rindereri and $V$. underwoodi . In $A$. mellifera, $V$. destructor reproduces in both worker and drone brood (Anderson and Trueman 2000; Rosenkranz et al. 2010). Female Varroa mites enter brood cells before capping, with total developmental time about 6 days (Ifantidis 1990). One female can produce an average of 1.8 and 3 mature daughters in worker and drone brood cells, respectively (Donzé et al. 1996). Mating occurs within the capped brood cell; young mated adults subsequently leave the cell with the emerging bee. Phoresy is a very important phase on the survival, dispersal, and even reproductive success of Varroa mites. The phoretic stage lasts from 4 days to a few months, depending on the availability of brood (Martin 1998; Beetsma et al. 1999). While phoretic, mites can feed on adult bees through soft membranes such as those between abdominal tergites (De D'Aubeterre et al. 1999).

Similar to other regions of the world, parasitism by Varroa can have devastating consequences for honeybees such as reduced longevity, immunosuppression, and increased viral prevalence and intensity (Rosenkranz et al. 2010). However, pathogenicity is largely specific to the particular mite and honeybee species considered, with natural parasite-host associations typically less pathogenic. In A. mellifera, bee parasitic mite syndrome is a disease complex of colonies simultaneously infested with $V$. destructor mites and infected with viruses (Shimanuki et al. 1994). Detection of bee viruses in Varroa mites suggests that mites are potential vectors that facilitate the horizontal transmission of bee viruses among honeybees (Chen and Siede 2007). The coexistence of several bee viruses (Kashmir bee virus (KBV), Acute bee paralysis virus (ABPV), Deformed wing virus (DWV), Sacbrood virus (SBV), and Black queen cell virus (BQCV)) in a single mite suggests that $V$. destructor can be responsible for multiple infections by viruses in apiaries in Thailand (Chantawannakul et al. 2006). This combination of mite infestation and viruses likely aggravates the health of colonies.

\subsubsection{Tropilaelaps spp.}

Four species of Tropilaelaps have been described in the mite family Laelapidae. First identified, Tropilaelaps clareae was collected from dead A. mellifera bees and field rats near beehives in the Philippines (Delfinado and Baker 1961). Twenty years later, Tropilaelaps koenigerum 
Table I. Differences in body size for all parasitic mites of honeybees in Asia.

\begin{tabular}{|c|c|c|c|c|}
\hline Mite species & Bee host & $\begin{array}{l}\text { Length } \\
(\mu \mathrm{m})\end{array}$ & $\begin{array}{l}\text { Width } \\
(\mu \mathrm{m})\end{array}$ & Reference \\
\hline \multicolumn{5}{|l|}{ Family Varroidae } \\
\hline Varroa jacobsoni & Ac & $1063-1077$ & $\begin{array}{l}1507- \\
1596\end{array}$ & $\begin{array}{l}\text { Anderson and Trueman (2000), } \\
\text { de Guzman and Delfinado-Baker } \\
\text { (1996) }\end{array}$ \\
\hline Varroa destructor & $\mathrm{Am}, \mathrm{Ac}$ & 1167 & 1709 & Anderson and Trueman (2000) \\
\hline Varroa rindereri & $\mathrm{Ak}$ & 1180 & 1698 & de Guzman and Delfinado-Baker (1996) \\
\hline Varroa underwoodi & Ac, Ani, Anu, Am & $690-820$ & $\begin{array}{l}1050- \\
1360\end{array}$ & $\begin{array}{l}\text { Delfinado-Baker and Aggarwal (1987), } \\
\text { Anderson et al. (1997), } \\
\text { de Guzman and Rinderer (1999) }\end{array}$ \\
\hline Euvarroa sinhai & Af & 1040 & 1000 & Delfinado and Baker (1974) \\
\hline Euvarroa wongsirii & $\mathrm{Aa}$ & 1000 & 1125 & Lekprayoon and Tangkanasing (1991) \\
\hline \multicolumn{5}{|l|}{ Family Laelapidae } \\
\hline Tropilaelaps clareae & Am, Adbr, Adbi & $882-976$ & $485-528$ & $\begin{array}{l}\text { Delfinado and Baker (1961), } \\
\text { Anderson and Morgan (2007) }\end{array}$ \\
\hline $\begin{array}{l}\text { Tropilaelaps } \\
\text { mercedesae }\end{array}$ & $\mathrm{Am}$ & 979 & 542 & Anderson and Morgan 2007 \\
\hline $\begin{array}{l}\text { Tropilaelaps } \\
\text { koenigerum }\end{array}$ & $\mathrm{Ad}, \mathrm{Al}$ & $684-713$ & $428-456$ & $\begin{array}{l}\text { Delfinado-Baker and Baker (1982), } \\
\text { Anderson and Morgan (2007) }\end{array}$ \\
\hline Tropilaelaps thaii & $\mathrm{Al}$ & 890 & 492 & Anderson and Morgan (2007) \\
\hline \multicolumn{5}{|l|}{ Family Tarsonemidae } \\
\hline Acarapis woodi & $\mathrm{Am}$ & 151 & 86 & Eckert (1961) \\
\hline Acarapis dorsalis & $\mathrm{Am}$ & 151 & 81 & Eckert (1961) \\
\hline Acarapis externus & $\mathrm{Am}$ & 170 & 105 & Eckert (1961) \\
\hline
\end{tabular}

Aa, A. andreniformis; Ac, A. cerana; Ad, A. dorsata; Adbi, A. d. binghami; Adbr, A. d. breviligula; Af, A. florea; Ak, A. koschevnikovi; Al, A. laboriosa; Am, A. mellifera; Ani, A. nigrocincta; Anu, A. nuluensis

was observed parasitizing A. dorsata in Sri Lanka (Delfinado-Baker and Baker 1982). More recently, Anderson and Morgan (2007) described two species, Tropilaelaps mercedesae and Tropilaelaps thaii parasitizing A. dorsata and A. mellifera in mainland Asia and A. laboriosa in the Himalayas, respectively. Similar to the reclassification of $V$. jacobsoni and $V$. destructor (Anderson and Trueman 2000), T. mercedesae was initially described as T. clareae (Anderson and Morgan 2007).

Tropilaelaps mites are believed to be indigenous parasites of the giant honeybees, A. dorsata, A. laboriosa, and A. breviligula (Laigo and Morse 1968; Delfinado-Baker et al. 1985; Anderson and Morgan 2007). Since its discovery, all reports on Tropilaelaps are from the distribution range of the giant honeybees and therefore suggest coevolution (Anderson and Morgan 2007). T. clareae was first observed infesting A. mellifera in the Philippines and recently found parasitizing A. breviligula in the Philippines and Sulawesi Island in Indonesia (Anderson and Morgan 2007). Reclassification of T. mercedesae by Anderson and Morgan (2007) suggests that the mite parasitizes $A$. dorsata and $A$. mellifera throughout southern mainland Asia and Indonesia, apart from Sulawesi Island, as well as A. laboriosa in the Himalayas (Figure 3). Earlier studies classifying $T$. mercedesae as $T$. clareae (Delfinado-Baker 1982; Kapil and Aggarwal 1987; Delfinado-Baker et al. 1989; Wongsiri et al. 1989; Abrol and Putatunda 1995; Koeniger et al. 2002) need to be reexamined. T. koenigerum is a parasite of $A$. dorsata in Sri Lanka, mainland Asia, and Indonesia apart from Sulwasesi and 


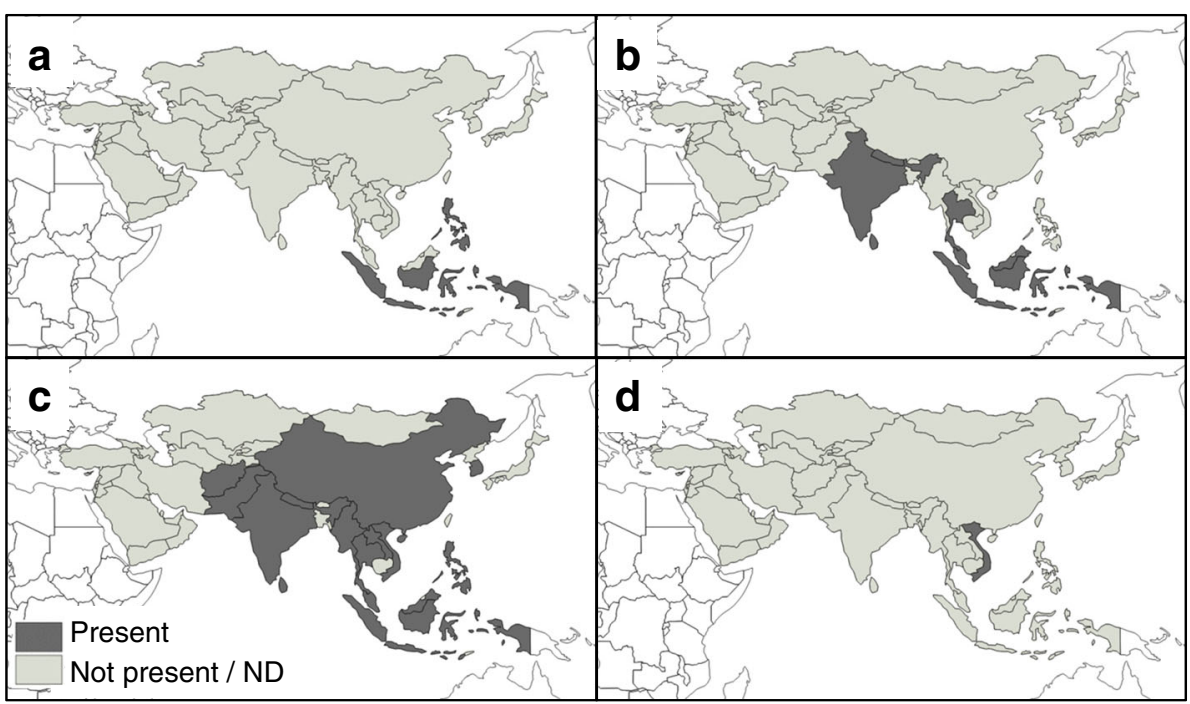

Figure 3. Distribution map of Tropilaelaps spp. in Asia. a Tropilaelaps clareae, b Tropilaelaps koenigerum, c Tropilaelaps mercedesae, and d Tropilaelaps thaii. Dark gray indicates Asian countries where the parasite has been detected in at least one honeybee species; light gray indicates Asian countries where the parasite has not been detected or no data $(N D)$ are available.

Borneo (Delfinado-Baker and Baker 1982; Anderson and Morgan 2007) and is known to coinfest $A$. dorsata colonies in Borneo and Thailand with T. mercedesae (Delfinado-Baker et al. 1989; Koeniger et al. 2002). Reproduction by T. koenigerum on A. cerana brood was observed in India (Abrol and Putatunda 1995) and by one adult $T$. mercedesae in Thailand (Anderson and Morgan 2007). T. koenigerum has only been observed in $A$. mellifera debris in Thailand (Kavinseksan, personal communication). Conversely, T. thaii has only been observed parasitizing A. laboriosa in Vietnam (Anderson and Morgan 2007).

Molecular and morphological techniques can be used to identify Tropilaelaps and to study their evolutionary history (Anderson and Morgan 2007). Morphologically, several characters are used to distinguish them, including body size, apex of the epigynial plate, anal plate shape, structure of the apical tooth of the chelicerae, and configuration of the apex of male spermatodactyl. T. mercedesae is larger than $T$. clareae or $T$. thaii, with $T$. koenigerum the smallest (Table I). Molecularly, the most comprehensive survey of Tropilaelaps mites to date by Anderson and Morgan (2007) using multiple gene sequences revealed that of 89 widespread isolates, 46 haplotypes fell into four lineages that can each be considered a separate species. Genetic differences within species were also identified, but require further investigation to better understand their intraspecies phylogenetic relationships.

Much of the life cycle of Tropilaelaps is based on $T$. mercedesae infesting A. mellifera colonies during a period when it was previously classified as $T$. clareae. Hence, reexaminations are warranted. Like Varroa or Euvarroa, Tropilaelaps also enters brood cells before they are sealed to complete their life cycle (Sammataro 2011). Foundress mites start to lay eggs shortly before the brood cell is capped, which allows nearly all progeny to reach adulthood before the adult bee emerges (Ritter and Schneider-Ritter 1988). The development time for mites is estimated to be approximately 6 and 8.7 days in vivo (Woyke 1987c) and in vitro, respectively (Kitprasert 1984), and a single foundress can produce up to four progeny (Woyke 1987b). Unlike Varroa and Euvarroa in its indigenous host, A. dorsata, Tropilaelaps appear to not show a gender preference between worker and drone brood (Koeniger et al. 2002; Buawangpong et al. 2013). The phoretic period of Tropilaelaps is short, surviving approximately 1- 
3 days on adult bees in vitro (Kitprasert 1984; Woyke 1984; Koeniger and Musaffar 1988; Rinderer et al. 1994). As a result, rapid oviposition, reduced life cycle period, and reproduction in both worker and drone brood cells contribute to relatively higher populations of Tropilaelaps in colonies compared to Varroa or Euvarroa (Buawangpong et al. 2015). When both $T$. mercedesae and $V$. destructor are experimentally introduced into an individual brood cell of A. mellifera, normal reproduction of both mites was observed (Buawangpong et al. 2015). Natural coinfestation of Varroa and Tropilaelaps does occur in A. mellifera brood; however, this is rare $(<0.1 \%)$ (Buawangpong et al. 2015). Additionally, $T$. koenigerum and $T$. mercedesae have been found infesting the same $A$. dorsata colony, but not the same brood cell (Delfinado-Baker et al. 1989; Koeniger et al. 2002).

Like Varroa and Euvarroa, pathogenicity of Tropilaelaps is believed to be closely tied to specific parasite-host associations. Few studies have evaluated the effects of these mites on honeybees, particularly their native hosts. Anecdotal reports suggest $T$. mercedesae and $T$. clareae severely affect $A$. mellifera throughout the region, whereas T. koenigerum and T. thaii are believed to be harmless to A. mellifera (Burgett et al. 1983; Anderson and Morgan 2007). By using artificial mite inoculation in A. mellifera brood, the proportion of nonreproductive $T$. mercedesae was found to be lower than that of $V$. destructor. Both mites produced similar numbers of progeny. In natural infestations of $A$. mellifera in Thailand, the average worker brood infestations of T. mercedesae (19.9\%) were significantly higher than that of $V$. destructor $(0.7 \%)$. This higher prevalence and reproductive ability of T. mercedesae in concurrently infested colonies reaffirm the competitive advantage of $T$. mercedesae over $V$. destructo $\mathrm{r}$ and their reported negative impact to $A$. mellifera colonies (Buawangpong et al. 2015). Additionally, T. mercedesae-inoculated A. mellifera pupae showed higher levels and incidence of DWV compared to uninfested pupae (Khongphinitbunjong et al. 2015). The mite has been shown to promote wing deformation and reduce bee longevity in Thailand
(Khongphinitbunjong et al., submitted). Both surveys in China and Thailand suggest the mite can vector DWV (Dainat et al. 2008; Forsgren et al. 2009; Khongphinitbunjong et al. 2015). However, no other bee viruses could be found in T. mercedesae and suggest that the major impact of mite infestation is caused by the mite itself (Khongphinitbunjong et al. 2015).

In contrary, Tropilaelaps populations are generally found to be low in their natural giant honeybee hosts (Buawangpong et al. 2013). Likely the result of parasite-host coevolution, A. dorsata exhibits a high grooming behavior against T. mercedesae when compared to A. mellifera (Büchler et al. 1992; Koeniger et al. 2002; Khongphinitbunjong et al. 2012). Under artificial mite inoculation, A. mellifera removed brood infested with T. mercedesae (52.6 \%) and peaked during the second and third days post-inoculation (Khongphinitbunjong et al. 2014). Information on hygienic behavior of giant honeybee against Tropilaelaps is not available. However, frequent absconding, possibly triggered by high mite infestation, or migration away from the nest, may also play important roles in the suppression of Tropilaelaps populations (Koeniger et al. 2002), as would its inability to feed on adult bees (Kitprasert 1984; Woyke 1984; Koeniger and Musaffar 1988; Rinderer et al. 1994; Kavinseksan et al. 2003).

Control of Varroa and Tropilaelaps mites . Numerous strategies for managing economically important mites of honeybees exist, including the use of chemotherapy, physical, and cultural methods (Sammataro 2011). When unmanaged, Varroa and Tropilaelaps are responsible for the rapid decline in colony health of $A$. mellifera colonies in Asia (Wongsiri and Tangkanasing 1987; Buawangpong et al. 2015). Although all Asian honeybees have mites associated with them, only A. mellifera colonies are managed for mite control because of the relative ease of their management and because the severe economic penalties this species faces when mites are not controlled (Wongsiri and Tangkanasing 1987). Many acaricides used for $V$. destructor control also likely work for Tropilaelaps (Sammataro 2011), including tau-fluvalinate, amitraz, formic acid, and 
thymol for T. clareae on A. mellifera in Thailand (Wongsiri and Tangkanasing 1987; Burgett and Kitprasert 1990), Vietnam (Woyke 1987a), and Pakistan (Raffique et al. 2012), respectively. Currently, the use of fluvalinate and coumaphos is widespread throughout the region (Wongsiri and Tangkanasing 1987; Akratanakul 1990). Due to the apparent short lifespan of Tropilaelaps on adult bees, interrupting brood rearing by queen caging or by removing all brood from colonies are effective to control T. mercedesae in Pakistan (Woyke 1984, 1985). Furthermore, leaves of alagaw (Premna odorata) and lemon grass (Andropogon citratus) are used to manage both mites with mixed success in the Philippines (Cervancia 1993; Booppha et al. 2010). Breeding for Varroa or Tropilaelaps resistance has not gained much popularity among Asian countries.

\subsubsection{Euvarroa spp.}

To date, two species from the genus Euvarroa are believed to be associated with five honeybee species in Asia: the open-air nesters A. andreniformis, A. florea, A. dorsata, as well as the cavity nesters $A$. cerana and $A$. mellifera. Euvarroa sinhai was first observed from A. florea samples collected in 1971 in India (Delfinado and Baker 1974), and Euvarroa wongsirii was first observed in A. andreniformis in Thailand (Lekprayoon and Tangkanasing 1991). These two Euvarroa species can be easily distinguished by the shape of their body and number of marginal setae. E. sinhai is pear-shaped with 39-40 marginal setae, whereas E. wongsirii is triangular or wider posteriorly with 47-54 long setae (Delfinado and Baker 1974; Lekprayoon and Tangkanasing 1991).

Infestations by $E$. wongsirii have only been reported in A. andreniformis in Thailand and Malaysia (Lekprayoon and Tangkanasing 1991). E. sinhai has been reported in A. florea in India, Iran, Sri Lanka, and Thailand (Delfinado and Baker 1974; Koeniger et al. 1983; Mossadegh 1991) and $A$. andreniformis in Thailand (Delfinado-Baker et al. 1989). E. wongsirii has not been observed in A. florea nests. Nevertheless, both mites have been collected from hive debris, with $E$. sinhai from A. mellifera colonies in India and Thailand (Kapil and Aggarwal 1987; Lekprayoon and Tangkanasing 1991) and E. wongsirii from A. dorsata in Borneo (Koeniger et al. 2002) (Figure 4). Euvarroa infestations are generally low in honeybee colonies, with decreased infestation likely due to host hygienic behavior of dwarf honeybee workers removing dead brood together with their infesting mites (Kitprasert 1995). Limited food supply of the single comb open-air nesters, as well as reduced brood cell diameter of dwarf honeybees, may also contribute to suppressed mite populations (Rinderer et al. 1996). Drone reproduction is also seasonal and swarming further reduces Euvarroa populations within colonies by disrupting bee brood and hence mite reproduction (Kitprasert 1995).

Compared to Varroa, the life history of Euvarroa is not well studied. The limited biological information available is based on observations of E. sinhai only, but the life history of the species appears to be similar to that of Varroa by parasitizing brood (Sammataro 2011). In vitro study using A. mellifera worker brood determined that the life cycle of $E$. sinhai is 5 days for males and 6-7 days for females, which can produce 4.3 progeny per infested A. mellifera (Mossadegh 1990). E. sinhai also prefers $A$. florea drones over workers (Akratanakul 1975; Mossadegh 1991; Kitprasert 1995). In some cases, a single brood cell can have up to 15 mites (Akratanakul 1975), which may lead to the death of the drone brood (Kitprasert 1995). It appears that the average reproduction of a foundress mite is higher in queenless (3.6 progeny/host) than in queenright (3.3 mites/host) colonies, with seven maximum progeny (Kitprasert 1995). Post-emergence, the mite can survive on adult workers for 4 to 10.5 months during broodless periods (Mossadegh 1990). In the laboratory, $E$. sinhai displayed higher survival on adult A. mellifera workers compared to A. cerana (Koeniger et al. 1993).

\subsubsection{Acarapis spp.}

Three species of mites are known from the genus Acarapis ; all are parasites of adult honeybees. First classified was Acarapis woodi in the early 1900s in England's Isle of Wight (Rennie 


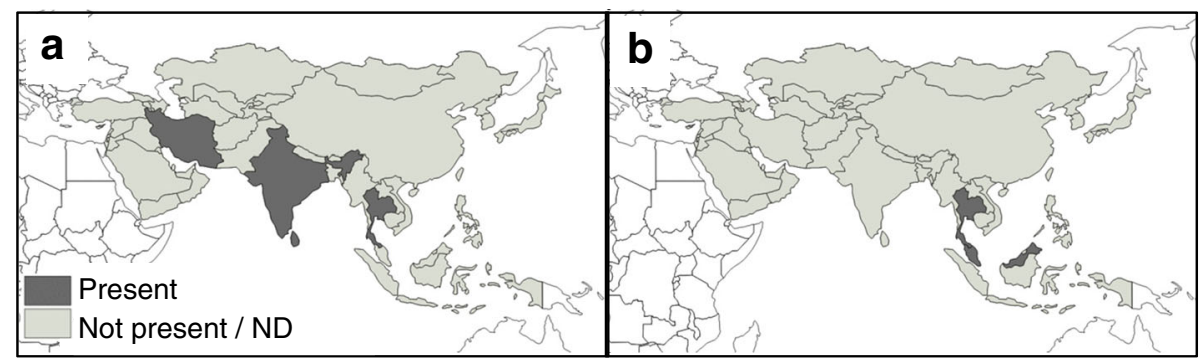

Figure 4. Distribution map of Euvarroa spp. in Asia. a Euvarroa sinhai and b Euvarroa wongsirii. Dark gray indicates Asian countries where the parasite has been detected in at least one honeybee species; light gray indicates Asian countries where the parasite has not been detected or no data $(N D)$ are available.

1921), followed by Acarapis dorsalis and Acarapis externus on several continents (Morgenthaler 1934). All three species parasitize honeybees in Asia.

The distribution of the three Acarapis species in Asia is not well established. The first report of A. woodi parasitizing honeybees in the region came from India (Michael 1957; Milne 1957). The species has since been observed parasitizing A. mellifera in Egypt, Iran, Israel, Jordan, Kuwait, Lebanon, Palestine, and Syria (Matheson 1993; Rashad et al. 1985; Gerson et al. 1994; Mossadegh and Bahreini 1994; Amr et al. 1998; OIE 2004), and A. indica in India, Pakistan, Bangladesh, and China (Delfinado and Baker 1982). Recently, $A$. woodi was observed in dead bees from collapsing colonies of $A$. cerana japonica in Japan (Kojima et al. 2011). It was also detected in Bhutan, Nepal, Hong Kong and Thailand; however, the honeybee host was not identified (Matheson 1993; Matheson 1995). Only in Iran has $A$. dorsalis and $A$. externus been reported, in this case parasitizing $A$. mellifera colonies (Mossadegh and Bahreini 1994).

The three Acarapis species are morphologically similar and are usually identified by the location where they are observed on a honeybee host, in addition to specific morphological differences (Eckert 1961; Delfinado-Baker and Baker 1982). A. externus is the largest (Table I). Examination of the distal line of the sternal plates is the most definitive defining feature of each species (Eckert 1961). Molecular tools have also been developed to identify Acarapis species (Evans et al. 2007). The total developmental time for $A$. woodi is 11 days, whereas $A$. dorsalis and $A$. externus take 8-9 days (Royce et al. 1988; Ibay 1989; de Guzman et al. 2001). Eckert (1961) claimed that a female A. dorsalis or A. externus can lay 2-5 eggs compared an average of 6 eggs for A. woodi (Royce et al. 1988).

Although all three Acarapis species feed on bee hemolymph, only $A$. woodi is considered to be of economic importance despite the death of colonies highly infested with $A$. externus (Ibay 1989; de Guzman et al. 2001). General symptoms of parasitism by $A$. woodi, at least in $A$. indica and $A$. mellifera, includes bees crawling in front of the hive, a distended abdomen, K-wing, and damaged trachea (Atwal 1971; Sammataro 2011). Virus-like particles have been observed in A. woodi (Liu 1991); however, thorough examinations of the potential for the mite to vector viruses like Varroa and Tropilaelaps mites are lacking.

\subsection{Viruses}

Viruses of honeybees are nearly ubiquitously distributed throughout the world, with more than 18 isolated to date (Bailey and Ball 1991; Allen and Ball 1996; Chen and Siede 2007). Among them, seven are common including BQCV, DWV, KBV, SBV, ABPV, Chronic bee paralysis virus (CBPV), and Israeli acute paralysis virus (IAPV) (Chen and Siede 2007). In Asia, these seven viruses have been reported to infect different honeybee species throughout the region (Sanpa and Chantawannakul 2009; Ai et al. 2012; Forsgren et al. 2015). Based on their genomic structures, SBV and DWV are classified under 
Iflaviridae, whereas BQCV, ABPV, KBV, and IAPV belong to the Dicistroviridae.

\subsubsection{Iflaviridae}

Of the viruses, SBV is the first virus discovered in A. mellifera (White 1913). Historical records from Asia showed that Sacbrood disease was first detected in A. cerana from Thailand in 1976 (Bailey et al. 1982). It was named Thailand sacbrood virus (TSBV, also known as Chinese sacbrood virus) since it was serologically related to SBV but physiochemically distinct (Bailey et al. 1982). TSBV caused death of greater than $90 \%$ of domesticated A. cerana populations in Kashmir (Abrol and Bhat 1990) and was also found in A. dorsata and A. florea in India (Allen and Ball 1996). In A. cerana, it was observed in India, Thailand, South Korea, Japan, Nepal, China, and Vietnam (Shah and Shah 1988; Allen and Ball 1996; Choi et al. 2008; Kojima et al. 2011; Grabensteiner et al. 2007; Ai et al. 2012; Forsgren et al. 2015). SBV infection of $A$. mellifera colonies was detected in Thailand, South Korea, Japan, China, and Vietnam (Sanpa and Chantawannakul 2009; Yoo et al. 2009; Kojima et al. 2011; Ai et al. 2012; Forsgren et al. 2015).

DWV appears to be more prevalent than SBV in four honeybee hosts. In A. mellifera, it was detected in Sri Lanka, Nepal, Thailand, Japan, China, and Vietnam (Berényi et al. 2007; Sanpa and Chantawannakul 2009; Kojima et al. 2011; Ai et al. 2012; Forsgren et al. 2015). DWV infections of $A$. cerana have been reported in China, South Korea, Japan, and Vietnam (Kojima et al. 2011; Ai et al. 2012; Li et al. 2012; Forsgren et al. 2015) and of $A$. florea and A. dorsata in China (Zhang et al. 2012). The virus was detected in $V$. destructor and T. mercedesae mites, and higher levels of DWV were detected in A. mellifera infested by the mites in Thailand ( Chantawannakul et a 1.2006 ; Khongphinitbunjong et al. 2015).

\subsubsection{Dicistroviridae}

BQCV was first isolated from queen larvae and pupae of $A$. mellifera found dead within their cells (Bailey and Woods 1977). The virus is highly prevalent in A. mellifera in Thailand, South Korea, China, Japan, and Vietnam ( Sanpa and Chantawannakul 2009; Ai et al. 2012; Yang et al. 2013; Reddy et al. 2013; Kojima et al. 2011; Forsgren et al. 2015); in A. cerana in South Korea, China, Vietnam, Thailand, and Japan (Li et al. 2012; Choe et al. 2012; Yang et al. 2013; Forsgren et al. 2015; Mookhploy et al. 2015); and in A. florea and A. dorsata from China and Thailand (Zhang et al. 2012; Mookhploy et al. 2015). Genetic variations of BQCV strains across four species of honeybees have been studied. Based on the capsid coding region, the phylogenetic analysis revealed that $\mathrm{BQCV}$ isolates from northern Thailand, China, South Korea, and Japan displayed a close relationship within Asia and split separately from South Africa and European regions, regardless of the host bee species from which the samples originated (Mookhploy et al. 2015). Similar findings were reported with the BQCV strains in Korea and Japan where the viral isolates from the same country or continent showed high levels of similarity (Kojima et al. 2011; Noh et al. 2013). The role of BQCV in honeybee mortality is currently poorly understood, particularly in association with other parasites such as the microsporidian Nosema apis (Bailey et al. 1983).

ABPV, KBV, and IAPV are part of a complex of related viruses (Chen and Siede 2007; de Miranda et al. 2010). KBV was first confirmed in A. cerana in India (Bailey and Woods 1977) and subsequently in South Korea (Choe et al. 2012). Surveys of bee viruses in A. mellifera colonies found KBV in Thailand (Sanpa and Chantawannakul 2009). Interestingly, KBV was not found in China and Vietnam during the disease surveys in both $A$. cerana and A. mellifera (Ai et al. 2012; Forsgren et al. 2015). ABPV has only been detected in A. cerana (Choe et al. 2012) and in A. mellifera in China (Ai et al. 2012; Forsgren et al. 2015) and Thailand (Sanpa and Chantawannakul 2009). IAPV has been detected in both $A$. mellifera and A. cerana: in A. mellifera in China (Ai et al. 2012), South Korea (Reddy et al. 2013), Japan (Morimoto et al. 2012), and Israel (Maori et al. 2007) and in A. cerana in China (Ai et al. 2012) and Japan (Kojima et al. 2011). 
These viruses have been associated with honeybee colony losses, particularly when colonies are coinfested with $V$. destructor (Cox-Foster et al. 2007; de Miranda et al. 2010). In northern Thailand, KBV was only found when $V$. destructor prevalence was high in A. mellifera colonies (Sanpa and Chantawannakul 2009).

\subsection{Fungi}

\subsubsection{Nosema spp.}

Two species of parasites belonging to this genus are known to infect honeybees, and both occur in Asia (Klee et al. 2007). N. apis, first described in the early 1900s in Europe (Zander 1909), is believed to historically parasitize A. mellifera (Fries 1993). N. ceranae appears to have an Asian origin (Botías et al. 2012) since it was first detected in A. cerana in China in the late 1990s (Fries et al. 1996).

Surveys have identified $N$. apis in A. mellifera (e.g., Klee et al. 2007) and A. cerana (Rice 2001) only. In contrast, $N$. ceranae parasitizes a broader array of hosts such as A. mellifera, A. cerana, A. florea, A. dorsata, and A. koschevnikovi (e.g., Klee et al. 2007; Chaimanee et al. 2010; Botías et al. 2012). Although both parasites have been detected throughout the region, $N$. ceranae appears to be more widespread (Figure $5 \mathrm{a}, \mathrm{b}$ ). In A. mellifera, $N$. ceranae was identified in Taiwan (Huang et al. 2007), Vietnam (Klee et al. 2007), China (Liu et al. 2008), Thailand (Chaimanee et al. 2010), Turkey (Whitaker et al. 2011), Indonesia (Botías et al. 2012), Solomon Islands (Botías et al. 2012), Japan (Yoshiyama and Kimura 2011), and Jordan (Haddad 2014). $N$. apis was detected in Israel (Gatehouse and Malone 1999), Indonesia (Rice 2001), and Turkey (Whitaker et al. 2011). A. mellifera colonies in China (Liu et al. 2008), Thailand (Chaimanee et al. 2010), or Jordan (Haddad 2014) were not infected with $N$. apis. Investigations of the incidence of Nosema spp. on honeybees native to Asia have been less thorough. In A. cerana, $N$. ceranae was identified in China, Vietnam, Indonesia, Solomon Islands, and Thailand (Fries et al. 1996; Klee et al. 2007; Li et al. 2012;
Forsgren et al. 2015; Botías et al. 2012; Chaimanee et al. 2010) and also detected in A. florea and A. dorsata in Thailand (Chaimanee et al. 2010).

Studies comparing the phylogenetic relationships among $N$. ceranae isolated from four different honeybee species in Thailand using polar tube proteins, important for microsporidian host invasion, showed three distinct clades (Chaimanee et al. 2011). N. ceranae isolated from A. mellifera grouped into the same clade as $N$. ceranae isolated from A. cerana, while $N$. ceranae isolated from A. florea and $A$. dorsata formed distinct clades. $A$. mellifera and $A$. cerana are cavity-nesting honeybees and are therefore more related to each other than to open-air, single comb-nesting species such as $A$. dorsata and A. florea (Alexander 1991). Therefore, the formation of a single clade for $N$. ceranae isolates from the cavity-nesting species reflects the genetic lineage of $A$. mellifera and A. cerana and suggests ongoing coevolution of this pathogen and its host. This is interesting considering that the parasite supposedly came from A. cerana. In China, however, studies using the $16 \mathrm{~S}$ ribosomal RNA gene demonstrated that $N$. ceranae infecting A. cerana in the north and south were distinct and also different from $N$. cerana e circulating in A. mellifera worldwide. Thai isolates fell into the same clade as those from southern China (Li et al. 2012).

Although Nosema are considered to be generalists, parasitizing a broad array of honeybee hosts, their prevalence and intensity of infection are different for each species. For $N$. ceranae, it appears that prevalence of infections in native honeybees is much lower compared to A. mellifera, as colonies surveyed in Thailand revealed infection prevalences of $77.5,22.2,45.4$, and $37.5 \%$ for A. mellifera, A. cerana, A. florea, and A. dorsata, respectively (Chaimanee et al. 2010). When infected with $N$. ceranae obtained from A. mellifera from Thailand, all four honeybee species became infected. However, different levels of intensity were observed. The infection rate of $A$. dorsata was similar to that found in A. mellifera, but $A$. florea was lower and $A$. ceranae the lowest (Chaimanee et al. 2011). Suwannapong et al. (2011) also 


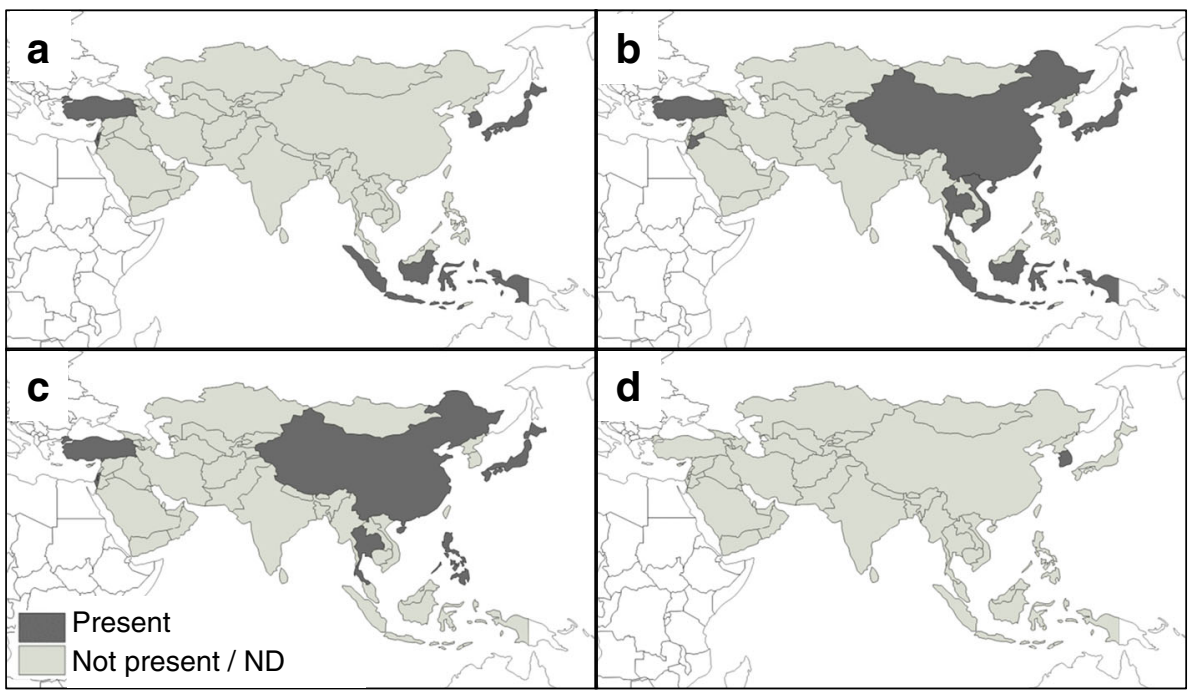

Figure 5. Distribution map of fungal pathogens and diseases in Asia. a Nosema apis, b Nosema ceranae, c Chalkbrood, and d Stonebrood. Dark gray indicates Asian countries where the parasite has been detected in at least one honeybee species; light gray indicates Asian countries where the parasite has not been detected or no data (ND) are available.

observed that $N$. ceranae isolated from $A$. florea could infect $A$. ceranae and affect hypopharyngeal protein production and shorten their lifespan.

The virulence between $N$. ceranae strains from the original host $A$. cerana and A. mellifera has been explored in these two cavity-nesting species. $N$. ceranae isolated from A. mellifera had higher infectivity than the isolate from A. cerana in both A. mellifera and A. cerana (Chaimanee et al. 2013). It appears that no difference in infection rate occurred, but rather each host species had displayed varied immune-related gene expression patterns in response to the infection (Chaimanee and Chantawannakul 2015).

In response to infection, $A$. cerana $w$ orkers infected by $N$. ceranae tended to have lower bacterial populations, particularly Bifidobacterium and Pasteurellaceae that produce several antibiotic compounds important to host defense against parasites ( $\mathrm{Li}$ et al. 2012). $N$. ceranae may also promote the outbreak of other bee diseases, such as Chalkbrood (Hedtke et al. 2011).

Both parasites can be managed by the fungicide fumagillin, but to varying degrees of success that require further examination of timing and quantity of treatments (Akratanakul 1990; Williams et al. 2008, 2011; Huang et al. 2013).

\subsubsection{Ascosphaera apis}

The fungus $A$. apis, which causes Chalkbrood disease in honeybees, was first described in the early twentieth century in A. mellifera in Europe (Maassen 1913) and now is found throughout the world. In Asia, incidence of Chalkbrood has been reported in China, Israel, Japan, Korea, the Philippines, Russia, Thailand, and Turkey (Figure 5c) (Oldroyd and Wongsiri 2006; Aronstein and Murray 2010). In Turkey, it was believed to have been introduced from contaminated beeswax which was imported to the country (Tutkun et al. 1993). In the Philippines and Thailand, beekeepers often reported higher incidence of fungal infection during the wet season (Cervancia 1993; Chantawannakul and Puchanichanthranon 2005). Ingestion of the fungus by honeybee larvae allows A. apis to germinate within the gut and eventually penetrate the body cavity, resulting in significant mechanical and enzymatic damage; dead, dried larvae, named Chalkbrood mummies, can be observed within uncapped brood cells (Heath 1982; Aronstein and Murray 2010). The fungus can 
produce lytic enzymes (protease and beta-Nacetylglucosaminidase) that may be an important factor that assists fungal invasion in the bee larvae; the enzymatic patterns from Thai isolates were similar to the previous report of Spanish isolates (Theantana and Chantawannakul 2008). In A. mellifera, Chalkbrood disease can result in lowered colony productivity, but rarely results in colony death (Heath 1982; Aronstein and Murray 2010). It is also not considered to be a serious disease of honeybees in Asia, even though it has been reported more widespread than Stonebrood disease which is caused by fungi from the genus Aspergillus (Akratanakul 1990; Ra et al. 2012) (Figure 5c, d).

\subsection{Bacteria}

\subsubsection{Paenibacillus larvae}

P. larvae, the causative agent of a disease called American foulbrood (AFB), has a nearly ubiquitous distribution, including in Asia (Genersch 2010) (Figure 6a). The disease was found in A. cerana in India (Singh 1961) and A. mellifera in Taiwan (Yen and Chyn 1971). However, a survey conducted in 2003 in Thailand revealed that $A$. mellifera was free of this disease (National Bureau of Agricultural Commodity and Food Standards 2008). Bee larvae become infected when $P$. larvae spores are ingested; disease results in larvae that are brownish, semifluid, and glue-like, before drying to a hard scale on the lower cell wall (Genersch 2010). Scales are highly infective and contain millions of spores that may be infective for several decades (Hasemann 1961). When artificially fed spores of $P$. larvae, A. cerana showed more resistance to infection than A. mellifera (Ho and Chen 2001).

\subsubsection{Melissococcus plutonius}

M. plutonius is a ubiquitously distributed bacterium of honeybees that has been detected throughout Asia, including in A. mellifera (Akratanakul 1990), A. cerana (Diwan et al. 1971; Bailey 1974; Zhou et al. 2000; Rana et al. 2012), A. laboriosa (Allen et al. 1990), and $A$. florea (Saraithong et al. 2015) (Figure 6b). M. plutonius primarily affects honeybee larvae, causing a disease known as European foulbrood (EFB) that is characterized by dead, twisted, brood within their cells. Infected colonies can be killed if a high proportion of larvae are infected (Bailey and Ball 1991). EFB was detected in A. mellifera beekeeping in China, Vietnam, Japan, and Thailand (Forsgren et al. 2015; Aronstein and Murray 2010; Budge et al. 2010). In Thailand, EFB is particularly prevalent during the wet season (Akratanakul 1990). It was also reported to cause serious damage to colonies of A. cerana in China between 1972 and 1976 (Yang 2005), Vietnam (Forsgren et al. 2015), and recently, in Japan (Arai et al. 2012; Takamatsu et al. 2014). A phenotypically and genetically distinct $M$. plutonius strain has been isolated from $A$. cerana japonica; it is frequently found and more virulent than the typical strain (Arai et al. 2014; Takamatsu et al. 2014).

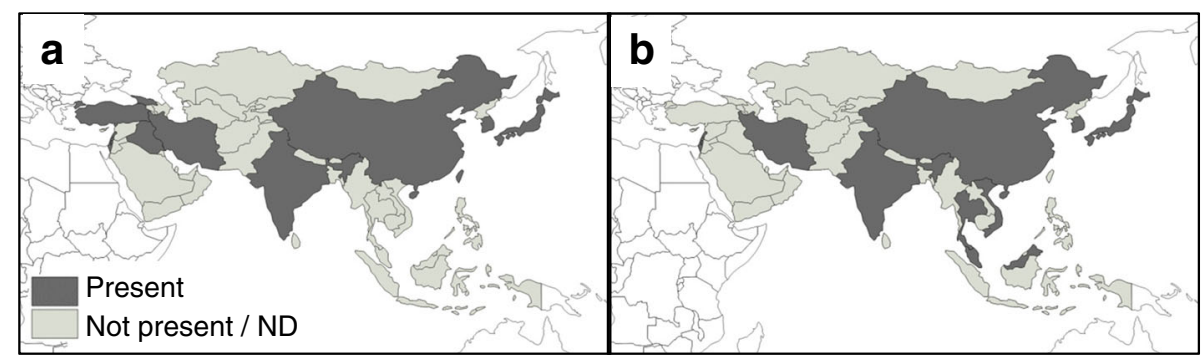

Figure 6. Distribution map of bacteria diseases. a American foulbrood and b European foulbrood in Asia. Dark gray indicates Asian countries where the parasite has been detected in at least one honeybee species; light gray indicates Asian countries where the parasite has not been detected or no data $(N D)$ are available. 


\subsection{Pests}

\subsubsection{Vertebrates}

Bee-eating birds. Bee-eating birds are also troublesome to $A$. mellifera; they include the little green bee eater (Merops orientalis), the chestnut headed bee eater (Merops leschenaulti), the swifts (Crypsiurus balasiensis, Chaetura spp.), the whitevented needletail (Hirundapus cochinchinesis), the wood peckers (Picus spp.), the honeyguides (Indicatoridae), the black drongo (Dicrurus macrocercus), the ashy drongo (Dicrurus leucophaeus), and the greater racket-tailed drongo (Dicrurus paradiseus) (Akratanakul 1990; Cervancia 1993; Wongsiri et al. 2005). In some cases, beekeepers will employ net-trapping to limit bird predation or relocate their colonies.

\subsubsection{Invertebrates}

Wax moths. Moth larvae attack the combs of honeybees worldwide. The greater wax moth, Galleria mellonella, and the lesser wax moth, Achroia gisella, are small nondescript moths that lay eggs in cracks and crevices of bee hives (Akratanakul 1990). Wax moths are a problem for unused or stored combs (Pernal and Clay 2013). Recently, larvae of $G$. mellonella attacking colonies of A. cerana japonica were collected in Japan. These samples also tested positive for IAPV and BQCV (Triyasut et al. 2015). The viruses were likely horizontally transmitted to the wax moth larvae by food or brood consumption within the colonies; however, viral replication in the wax moth larvae was not detected. Future work needs to clarify the possible role of bee viruses in moth larvae. In Southeast Asia, wax moths are a major pest of $A$. cerana, and causes them to abscond (Akratanakul 1990). Chemical controls are usually not applied for wax moth management. Instead, cultural measures such as removing hive debris, managing colonies to be strong, and removing or burning unused and infested combs are recommended.
Small hive beetle (Aethina tumida) A. tumida is now an emerging pest of honeybees in Asia since it was discovered in the region for the first time in the Philippines in 2014 (Brion 2015). Between June 2014 and April 2015, hundreds of A. mellifera colonies in Mindanao (southern Philippines) had been lost from SHB infestation. The beetle is an opportunistic scavenger (Neumann and Elzen 2004). Mild climates of southern Asia provide an exceptional environment for A. tumida; high temperatures shorten the development period of the beetle (de Guzman and Frake 2007), and year-round availability of food (brood, pollen, and honey) from multiple honeybee species promotes fecundity (de Guzman et al. 2015). Therefore, both native and introduced honeybee species, as well as stingless bees, are threatened by the beetle. Investigations are underway to adapt control measures employed in North America and Australia for the region.

Wasps (Vespa spp.). Vespa spp. are important predators of honeybees in Asia (Matsuura 1988). Entrances of honeybee colonies are often targeted, with one wasp capable of capturing seven bees in one attack (Cervancia 1993). Such a disturbance can result in A. cerana colonies to abscond. Furthermore, some species are known to predate on A. cerana drones at drone congregation areas (Koeniger et al. 1994). To deter predation, A. cerana, A. nuluensis, and $A$. dorsata perform body shaking as a defense mechanism (Koeniger et al. 1996; Kastberger et al. 1998; Tan et al. 2010; Khongphinitbunjong et al. 2012), and A. cerana and $A$. mellifera make tight balls that kill wasp intruders by heating (Ono et al. 1987; Tan et al. 2005). Beekeepers sometimes employ wasp traps or reduce the hive entrance and also frequently kill wasps by hitting them with slippers, pieces of wood, or badminton rackets (Cervancia 1993). Furthermore, toxic baits may be used to poison wasp nest mates.

Ants. Many ant species can cause problems in commercial beekeeping. Most frequent recorded ant species are weaver ant (Oecophylla smaragdina), black ants (Monomorium spp.), fire ants (Solenopsis spp.), and Formica spp. (Akratanakul 1990). 
Bee lice (Braula coeca) B. coeca wingless flies are not considered to be an important pest of honeybees (Pernal and Clay 2013). Larvae consume wax, pollen, and honey and tunnel through the combs. The adults eat nectar and pollen and steal food from the mouths of bees. Treatments for parasitic mites are also found effective against B. coeca (Kulincevic et al. 1991).

\section{CONCLUSIONS AND FUTURE PERSPECTIVES}

With the introduction of A. mellifera in the region, native Asian honeybees are also at a greater risk of pathogen and parasite infections from interspecies transmission routes. Likewise, A. mellifera could be susceptible to further pests and parasites from native honeybees, which was previously exemplified by infestation by $V$. destructor and N. ceranae (Fries 2010; Rosenkranz et al. 2010). The rich diversity of honeybees, pathogens, and parasites in Asia has attracted researchers around the world to better understand host-parasite evolution and to improve management of introduced exotic parasites of A. mellifera that have come from Asia by studying those parasites with their indigenous hosts. Many reports suggest that native Asian honeybees cope well with parasites that are currently devastating to A. mellifera using behavioral and immunological host defense mechanisms (Khongphinitbunjong et al. 2012; Chaimanee et al. 2010). The migratory nature of several species of native Asian honeybees may also affect susceptibility of infection or infestation (Kavinseksan et al. 2003). The resistance of Asian honeybees toward some bacterial pathogens may be due to their unique bacterial community structures inhibiting pathogen growth or infection. Studies have shown that gut bacteria in A. mellifera, A. cerana, A. florea, and A. dorsata differ, likely due to geographic location, life stage, and species of honeybees (Disayathanoowat et al. 2011; Saraithing et al. 2015a, b). Furthermore, some isolates of midgut bacteria inhibit growth of
American foulbrood causing P. larvae in vitro (Disayathanoowat et al. 2011, 2012). Honeybee hives also harbor actinomycetes, the main microbial groups that produce natural antibiotics (Promnuan et al. 2009, 2011), and hive components such as propolis and bee bread could also assist in safeguarding against some pests and parasites (Simone-Finstrom and Spivak 2012; Simone et al. 2009). Additionally, other nonbiological factors and management problems that plague not just honeybees, but other bees, could also result in decreased honeybee health in Asia. Increasing loss of foraging resources due to farming and urban encroachment may strain populations (Naug 2009). Pesticide exposure could also present high risks to honeybees, and a recent study revealed that organophosphates are highly toxic to A. cerana and A. mellifera (Stanley et al. 2015). The current policy of pollinator protection, especially honeybees, has not yet been successfully implemented in the region as honeybees are often undervalued or the value of honeybees is completely overlooked. Scientific information of honeybee pests and parasites in some regions are still lacking. In addition, standards and research on biomedical properties of bee products, such as honey (Wanjai et al. 2012) and propolis (Sanpa et al. 2015), are needed to promote beekeeping in Asia.

\section{ACKNOWLEDGMENTS}

P.C. would like to thank the Thailand Research Fund, National Research Council of Thailand and Chiang Mai University fund. G.R.W. thanks the Vinetum Foundation. Stephanie Rogers provided excellent mapping assistance for our figures.

Ravageurs, pathogènes et parasites des abeilles en Asie

Asie / virus / Tropilaelaps / Acari / abeilles asiatiques / santé des abeilles / agent pathogène

Schädlinge, Krankheiten und Parasiten von Honigbienen in Asien

Asien / Bienenviren / Tropilaelaps / Asiatische Bienenmilben / Honigbienen / Krankheitserreger 


\section{REFERENCES}

Abrol, D.P., Bhat, A.A. (1990) Studies on Thai sac brood virus affecting indigenous honey bee Apis cerana indica Fab colonies - prospects and future strategies. J. Anim. Morphol. Physiol. 37, 101-108

Abrol, D.P., Putatunda, B.N. (1995) Discovery of an ectoparasitic mite Tropilaelaps koenigerum DelifinadoBaker \& Baker on Apis dorsata, A. meliffera L. and Apis cerana $\mathrm{F}$. in Jammu and Kashmir, India. Current Sci 68,90

Ai, H., Yan, X., Han, R. (2012) Occurrence and prevalence of seven bee viruses in Apis mellifera and Apis cerana apiaries in China. J. Invertebr.Pathol 109, 160-164

Akratanakul, P. (1975) Biology and systematics of bee mites of the family Varroidae (Acari: Mesostigmata). MS Thesis. Oregon State University. pp 1-64

Akratanakul, P. (1990) Beekeeping in Asia. FAO (Food and Agriculture Organisation of the United Nations), Agricultural Services. Bulletin 68/4. Rome, Italy.

Alexander, B. (1991) A cladistics analysis of the genus Apis. In: Smith, D.R. (ed.) Diversity in the Genus Apis, pp. 1-28. Westview Press, Boulder

Allen, M.R., Ball, B.V. (1996) The incidence and world distribution of honey bee viruses. Bee World 77, 141162

Allen, M.F., Ball, B.V., Underwood, B.A. (1990) An isolate of Melissococcus pluton from Apis laboriosa. J. Invertebr. Pathol 55, 439-440

Amr, S.Z., Shehada, S.E., Abo-Shehada, M., Al-Oran, R. (1998) Honeybee parasitic arthropods in Jordan. Apiacta 3, 78-82

Anderson, D.L. (1994) Non-reproduction of Varroa jacobsoni in Apis mellifera colonies in Papua New Guinea and Indonesia. Apidologie 25, 412-421

Anderson, D.L. (2004) Varroa mites and their host relationships in the Philippines. Proceedings of the 7th Asian apicultural Association Conference and 10th Beenet Symposium and Technoflora, Laguna, Luzon, Philippines, pp. 177-178

Anderson, D.L., Sukarsih, D. (1996) Changed Varroa jacobsoni reproduction in Apis mellifera colonies in Java. Apidologie 27, 461-466

Anderson, D.L., Fuchs, S. (1998) Two genetically distinct populations of Varroa jacobsoni with contrasting reproductive abilities on Apis mellifera. J. Apic. Res. 37, 69-78

Anderson, D.L., Trueman, J.W.H. (2000) Varroa jacobsoni (Acari: Varroidae) is more than one species. Exp. Appl. Acarol. 24, 165-189

Anderson, D.L., Morgan, M.J. (2007) Genetic and morphological variation of bee-parasitic Tropilaelaps mites (Acari: Laelapidae): new and re-defined species. Exp. Appl. Acarol. 43, 1-24

Anderson, D.L., Halliday, R.B., Otis, G.W. (1997) The occurrence of Varroa underwoodi (Acarina:
Varroidae) in Papua New Guinea and Indonesia. Apidologie 28, 143-147

Arai, R., Tominaga, K., Wu, M., Okura, M., Ito, K., Okamura, N., Onishi, H., Osaki, M., Sugimura, Y., Yoshiyama, M., Takamatsu, D. (2012) Diversity of Melissococcus plutonius from honey bee larvae in Japan and experimental reproduction of European foulbrood with cultured atypical isolates. PLoS ONE 7, e33708

Arai, R., Miyoshi-Akiyama, T., Okumura, K., Morinaga, Y., Wu, M., Sugimura, Y., Yoshiyama, M., Okura, M., Kirakae, T., Takamatsu, D. (2014) Development of duplex PCR assay for detection and differentiation of typical and atypical Melissococcus plutonius strains. J. Vet. Med. Sci. 76, 491-498

Aronstein, K.A., Murray, K.D. (2010) Chalkbrood disease in honey bees. J. Invertebr. Pathol. 103, S20-S29

Atwal, A.S. (1971) Acarine disease problem of the Indian honey bee. Apis indica F. Am. Bee J. 111, 186-187

Bailey, L. (1974) An unusual type of Streptococcus pluton from the eastern hive bee. J. Invertebr. Pathol. 23, 246-247

Bailey, L., Woods, R.D. (1977) Two more small RNA viruses from honey bees and further observations on sacbrood and acute bee-paralysis viruses. J. Gen. Virol. 37 (1), 175-182

Bailey, L., Ball, B.V. (1991) Honey Bee Pathology, p. 193. Academic Press Ltd., London

Bailey, L., Ball, B.V., Carpenter, J.M., Woods, R.D. (1982) A strain of sacbrood virus from Apis cerana. J. Invertebr. Pathol. 39, 264-265

Bailey, L., Ball, B.V., Perry, J.N. (1983) Association of viruses with two protozoal pathogens of the honey bee. An. Appl. Biol. 103 , 13-20

Beetsma, J., Boot, W.J., Calis, J. (1999) Invasion behavior of Varroa jacobsoni Oud from bees into brood cells. Apidologie 30, 125-140

Berényi, O., Bakonyi, T., Derakhshifar, I., Koglberger, H., Topolska, G., Ritter, W., Pechhacker, H., Nowotny, N. (2007) Phylogenetic analysis of deformed wing virus genotypes from diverse geographic origins indicates recent global distribution of the virus. Appl. Environ. Microbiol. 73, 3605-3611

Botías, C., Anderson, D.L., Meana, A., Garrido-Bailón, E., Martín-Hernández, R., Higes, M. (2012) Further evidence of an oriental origin for Nosema ceranae (Microsporidia: Nosematidae). J. Invertebr. Pathol. 110 (1), 108-113

Booppha, B., Eittsayeam, S., Pengpat, K., Chantawannakul, P. (2010) Development of bioactive ceramics to control mite and microbial diseases in bee farms. Advanced Materials Research 93, 553-557

Brion, A.C. B. (2015) Small hive beetle poses threat to bee industry. The Philippine Star (February 22)

Buawangpong, N., Khongphinitbunjong, K., Chantawannakul, P., Burgett, M. (2013) Tropilaelaps 
mercedesae: Does the honey bee brood mite parasite exhibit a gender preference when infesting brood of the adapted host Apis dorsata? J. Apic. Res. 52, 158-159

Buawangpong, N., de Guzman, L.I., Frake, A.M., Khongphinitbunjong, K., Burgett, M., Chantawannakul, P. (2015) Tropilaelaps mercedesae and Varroa destructor: prevalence and reproduction in concurrently infested Apis mellifera colonies. Apidologie 46 . doi: 10.1007/s13592-015-0368-8

Büchler, R., Drescher, W., Tornier, I. (1992) Grooming behaviour of Apis cerana, Apis mellifera and Apis dorsata and its effects on the parasitic mites Varroa jacobsoni and Tropilaelaps clareae. Exp. Appl. Acarol. 16, 313-319

Budge, G.E., Barrett, B., Jones, B., Pietravalle, S., Marris, G., Chantawannakul, P., Thwaites, R., Hall, J., Cuthbertson, A.G., Brown, M.A. (2010) The occurrence of Melissococcus plutonius in healthy colonies of Apis mellifera and the efficacy of European foulbrood control measures. J. Invertebr. Pathol. 105, 164170

Burgett, D.M., Akratanakul, P., Morse, R. (1983) Tropilaelaps clareae: A parasite of honey bees in South East Asia. Bee world 64, 25-28

Burgett, D.M., Kitprasert, C. (1990) Evaluation of Apistan $^{\mathrm{TM}}$ as a control for Tropilaelaps clareae (Acari: Laelapidae), an Asian honey bee brood mite parasite. Am. Bee J. 130, 51-53

Cervancia, C.R. (1993) Philippines beekeeping status of research and development. In: Proc. Beenet Asia: Workshop on Priorities in R\&D on Beekeeping in Tropical Asia. Kuala Lumpur, Malaysia. pp. 49-63

Chaimanee, V., Chantawannakul, P. (2015) Infectivity of Nosema ceranae isolated from Apis cerana and A. mellifera . J. Apic. Res., in press

Chaimanee, V., Warrit, N., Chantawannakul, P. (2010) Infections of Nosema ceranae in four different honeybee species. J. Invertebr Pathol. 105, 207-210

Chaimanee, V., Chen, Y., Pettis, J.S., Scott Cornman, R., Chantawannakul, P. (2011) Phylogenetic analysis of Nosema ceranae isolated from European and Asian honeybees in Northern Thailand. J. Invertebr. Pathol. 107, 229-233

Chaimanee, V., Pettis, J.S., Chen, Y., Evans, J.D., Khongphinitbunjong, K., Chantawannakul, P. (2013) Susceptibility of four different honey bee species to Nosema ceranae. Vet. Parasitol. 193 (1-3), 260-265

Chantawannakul, P., Puchanichanthranon, T. (2005) Inhibitory effects of some medicinal plant extracts on the growth of Ascosphaera apis . Acta Hort. 678, 183-186

Chantawannakul, P., Ward, L., Boonham, N., Brown, M. (2006) A scientific note on the detection of honeybee viruses using real-time PCR (TaqMan) in Varroa mites collected from a Thai honeybee (Apis mellifera) apiary. J. Invertebr. Pathol. 91, 69-73

Chen, Y.P., Siede, R. (2007) Honey bee viruses. In: Karl Maramorosch, A.J.S., Frederick, A.M. (eds.) Advances in Virus Research. Academic Press, vol. 70, pp. $33-80$
Choe, S.E., Nguyen, L.T.K., Noh, J.H., Koh, H.B., Jean, Y.H., Kweon, C.H., Kang, S.W. (2012) Prevalence and distribution of six bee viruses in Korean Apis cerana populations. J. Invertebr. Pathol. 109 (3), 330-333

Choi, Y.S., Lee, M.L., Lee, M.Y., Lee, K.G. (2008) Occurrence of seven honey bee viruses and research of disease occurrence in Korean apiaries. Korean J. Apic. $23(2), 153-159$

Cox-Foster, D.L., Conlan, S., Holmes, E.C., Palacios, G., Evans, J.D., et al. (2007) A metagenomic survey of microbes in honey bee colony collapse disorder. Science 318 (5848), 283-287

Crane, E. (1999) The world history of beekeeping and honey hunting. Gerald Duckworth \& Co, Ltd, London

Crane, E. (2003) Making a bee-line. International Bee Research Association, Cardiff, United Kingdom

Dainat, B., Tan, K., Berthoud, H., Neumann, P. (2008) The ectoparasitic mite Tropilaelaps mercedesae (Acari, Laelapidae) as a vector of honeybee viruses. Insectes Soc. 56, 40-43

De D'Aubeterre, J.P., Myrold, D.D., Royce, L.A., Rossignol, P.A. (1999) A scientific note of an application of isotope ratio mass spectrometry to feeding by the mite, Varroa jacobsoni Oudemans, on the honeybee, Apis mellifera L. Apidologie 30, 351-352

de Guzman, L.I., Delfinado-Baker, M. (1996) A new species of Varroa (Acari: Varroidae) associated with Apis koschevnikovi (Apidae: Hymenoptera) in Borneo. Internat. J. Acarol. 22, 23-27

de Guzman, L.I., Rinderer, T.E. (1998) Distribution of the Japanese and Russian genotypes of Varroa jacobsoni . Honey Bee Sci. 19, 115-119

de Guzman, L.I., Rinderer, T.E. (1999) Identification and comparison of Varroa species identification and comparison of Varroa species infesting honey bees. Apidologie 30, 85-95

de Guzman, L.I., Frake, A.M. (2007) Temperature affects Aethina tumida (Coleoptera: Nitidulidae) development. J. Apic. Res. 46, 88-93

de Guzman, L.I., Rinderer, T.E., Whiteside, R. (1996) Scientific note on the infestation of Varroa on Apis nuluensis. Apidologie 27, 429-430

de Guzman, L.I., Rinderer, T.E., Stelzer, J.A. (1997) DNA evidence of the origin of Varroa jacobsoni Oudemans in the Americas. Biochem. Genet. 35, 327-335

de Guzman, L.I., Rinderer, T.E., Stelzer, J.A., Anderson, D.L. (1998) Congruence of RAPD and mitochondrial DNA markers in assessing Varroa jacobsoni genotypes. J. Apic. Res. 37, 49-51

de Guzman, L.I., Rinderer, T.E., Stelzer, J.A. (1999) Occurrence of two genotypes of Varroa jacobsoni Oud. in North America. Apidologie 30, 31-36

de Guzman, L.I., Burgett, D.M., Rinderer, T.E. (2001) Biology and life history of Acarapis dorsalis and Acarapis externus. In: Webster, T.C., Delaplane, K.S. (eds.) Mites of the honey bees, pp. 17-27. Dadant, Hamilton, IL 
de Guzman, L.I., Rinderer, T.E., Frake, A.M. (2015) Effects of diet, mating and temperature on ovary activation and fecundity of small hive beetles (Coleoptera: Nitidulidae). Apidologie 46(3), 326-336

de Jong, D. (1988) Varroa jacobsoni does reproduce in worker cells of Apis cerana in South Korea. Apidologie 19, 241-244

de Miranda, J.R., Cordoni, G., Budge, G. (2010) The acute bee paralysis virus-Kashmir bee virus-Israeli acute paralysis virus complex. J. Invertebr. Pathol 103 (Supplement), S30-S47

Delfinado, M., Baker, E.W. (1961) Tropilaelaps, a new genus of mites from the Philippines (Laelaptidae[s.lat]: Acarina). Fieldiana Zool 44, 53-56

Delfinado, M.D., Baker, E.W. (1974) Varroidae, a new family of mites on honey bees (Mesostigmata: Acarina). J. Wash. Acad. Sci. 64, 4-10

Delfinado, M.D., Baker, E.W. (1982) Notes on the honey bee mites of the genus Acarapis Hirts (acari: Tasrsonemidae). Internat. J. Acarol. 8, 211-226

Delfinado-Baker, M. (1982) New records for Tropilaelaps clareae from colonies of Apis cerana indica. Am. Bee J. 122, 382

Delfinado-Baker, M., Baker, E.W. (1982) A new species of Tropilaelaps parasitic on honey bees. Am. Bee J. 122, 416-417

Delfinado-Baker, M., Aggarwal, K. (1987) A new Varroa (Acari: Varroidae) from the nests of Apis cerana (Apidae). Int. J. Acarol. 13, 233-237

Delfinado-Baker, M., Underwood, B.A., Baker, E.W. (1985) The occurrence of Tropilaelaps mites in brood nests of Apis dorsata and A. laboriosa in Nepal, with descriptions of nymphal stages. Am. Bee J. 125, 703706

Delfinado-Baker, M., Baker, E.W., Phoon, A.C.G. (1989) Mites (Acari) associated with bees (Apidae) in Asia, with description of a new species. Am. Bee J. 129 (609-610), 612-613

Diwan, V.V., Kshirsagar, K.K., Ramama Rao, A.V., Raghunath, D., Bhambure, C.S., Godbole, S.H. (1971) Occurrence of a new bacterial disease of Indian honey bee Apis indica F. Curr. Sci. 40, 196.197

Disayathanoowat, T., Young, J.P.W., Helgason, T., Chantawannakul, P. (2011) T-RFLP analysis of bacterial communities in the midguts of Apis mellifera and Apis cerana honey bees in Thailand. FEMS Microbiol Ecol. 79(2), 273-281

Disayathanoowat, T., Yoshiyama, M., Kimura, K., Chantawannakul, P. (2012) Isolation and characterization of bacteria from the midgut of the Asian honey bee (Apis cerana indica). J. Apic. Res. 51 (4), 312-319

Donzé, G., Herrmann, M., Bachofen, B., Guerin, P.R.M. (1996) Effect of mating frequency and brood cell infestation rate on the reproductive success of the honeybee parasite Varroa jacobsoni. Ecol. Entomol. 21, $17-26$

Eckert, J.E. (1961) Acarapis mites of the honey bee Apis mellifera L. J. Insect Pathol. 3, 409-425
Ellis, J.D., Munn, P.A. (2005) The worldwide health status of honey bees. Bee World 86, 88-101

Evans, J.D., Pettis, J.S., Smith, I.B. (2007) A diagnostic genetic test for the honey bee tracheal mite, Acarapis woodi. J. Apic. Res. 46, 195-197

Food and Agriculture Organization of the United Nations (FAO) (2014) FAOSTAT.(http://faostat.fao.org)

Fries, I. (1993) Nosema apis - a parasite in the honey bee colony. Bee World 74 (1), 5-19

Fries, I. (2010) Nosema ceranae in European honey bees (Apis mellifera). J. Invertebr. Pathol. 103, S73-S79

Fries, I., Feng, F., Da Silva, A., Slemenda, S.B., Pieniazek, N.J. (1996) Nosema ceranae n. sp. (Microspora, Nosematidae), morphological and molecular characterization of a microsporidian parasite of the Asian honey bee Apis cerana (Hymenoptera, Apidae). Eur. J Protistol 32 (3), 356-36

Forsgren, E., de Miranda, J.R., Isaksson, M., Wei, S., Fries, I. (2009) Deformed wing virus associated with Tropilaelaps mercedesae infesting European honey bees (Apis mellifera). Exp. Appl. Acarol. 47, 87-97

Forsgren, E., Wei, S., Guiling, D., Zhiguang, L., Tran, T.V., Tang, P.T., Truong, T.A., Dinh, T.Q., Fries, I. (2015) Preliminary observations on possible pathogen spillover from Apis mellifera to Apis cerana. Apidologie 46, 265-275

Fuchs, S., Long, L., Anderson, D. (2000) A scientific note on the genetic distinctness of Varroa mites on Apis mellifera L. and on Apis cerana Fabr. in North Vietnam. Apidologie 31, 456-460

Gatehouse, H.S., Malone, L.A. (1999) Genetic variability among Nosema apis isolates. J. Apic. Res. 38, 79-85

Genersch, E. (2010) American Foulbrood in honeybees and its causative agent, Paenibacillus larvae. J. Invertebr. Pathol. 103, S10-S19

Gerson, U., Dag, A., Efrat, C., Slabezki, Y., Stern, Y. (1994) Tracheal mite, Acarapis woodi, comes to Israel. Am. Bee J. 134, 486

Grabensteiner, E., Bakonyi, T., Ritter, W., Pechhacker, H., Nowotny, N. (2007) Development of a multiplex RTPCR for the simultaneous detection of three viruses of the honeybee (Apis mellifera L.): Acute bee paralysis virus, Black queen cell virus and Sacbrood virus. J. Invertebr Pathol 94 (3), 222-225

Haddad, N.J. (2014) First detection of Nosema ceranae in Jordan. Eur. Sci. J. 10(33), 91-96

Hasemann, L. (1961) How long can spores of American foulbrood live? Am. Bee J. 101, 298-299

He, X., Liu, X.Y. (2011) Factor of Apis ceranae decline in China. Apiculture of China 62 (5), 21-23

Heath, L.A.F. (1982) Development of chalk brood in a honey bee colony; Chalkbrood pathogens: a review. Bee World 63 (3), 119-135

Hedtke, K., Jensen, P.M., Bruun, A., Genersch, E. (2011) Evidence for emerging parasites and 
pathogens influencing outbreaks of stress-related diseases like chalkbrood. J. Invertebr. Pathol. 108, 167-173

Hepburn, H.R., Hepburn, C. (2005) Bibliography of Apis florea. Apidologie 36, 377-378. doi:10.1051/ apido:2005024

Hepburn, R., Hepburn, C. (2006) Bibliography of Apis cerana Fabricius (1793). Apidologie 37, 651-652

Hepburn, R., Radloff, S.E. (2011) Honeybees of Asia, p. 669. Springer, Berlin

Hepburn, H.R., Radloff, S.E., Verma, S., Verma, L.R. (2001) Morphometric analysis of Apis cerana populations in the southern Himalayan region. Apidologie 32, 435-447

Hepburn, H.R., Radloff, S.E., Otis, G.W., Fuchs, S., Verma, L.R., Tan, K., Chaiyawong, T., Tahmasebi, G., Ebadi, R., Wongsiri, S. (2005) Apis florea: morphometrics, classification and biogeography. Apidologie 36, 359376

Ho, K., Chen, Y. (2001) Susceptibility of the Asian honey bee (Apis cerana) to American foulbrood (Paenibacillus larvae larvae). Proceeding of the 37th International Apicultural Congress. Durban, South Africa, pp. $1-8$

Huang, W.F., Jiang, J.H., Chen, Y.W., Wang, C.H. (2007) A Nosema ceranae isolate from the honeybee Apis mellifera. Apidologie 38, 30-37

Huang, W.F., Solter, L.F., Yau, P.M., Imai, B.S. (2013) Nosema ceranae escapes fumagillin control in honey bees. PLOS Pathogens 9 (3), e1003185

Ibay, L.I. (1989) Biology of the two external Acarapis species of honey bees: Acarapis dorsalis Morganthaler and Acarapis externus Morganthaler (Acari: Tarsonemidae). Oregon State University, USA

Ifantidis, M. (1990) Re-examination of the reproductive parameters of the mite Varroa jacobsoni Oudemans, pp. 20-26. Proc. Int. Symp. Bee Pathol. Gent, Belgium

Kapil, R.P., Aggarwal, K. (1987) Some observations on the concurrent parasitization of Apis florea by Tropilaelaps clareae and Euvarroa sinhai. Exp. Appl. Acarol. 3, 267-269

Kastberger, G., Raspotnig, G., Biswas, S., Winder, O. (1998) Evidence of Nasonov scenting in colony defence of the giant honeybee Apis dorsata. Ethology 104, 27-37

Kavinseksan, B., Wongsiri, S., de Guzman, L.I., Rinderer, T.E. (2003) Absence of Tropilaelaps infestation from recent swarms of Apis dorsata in Thailand. J. Apic. Res. 42, 49-50

Khongphinitbunjong, K., de Guzman, L., Burgett, M., Rinderer, T., Chantawannakul, P. (2012) Behavioral responses underpinning resistance and susceptibility of honeybees to Tropilaelaps mercedesae. Apidologie 43, 590-599

Khongphinitbunjong, K., de Guzman, L.I., Buawangpong, N., Rinderer, T.E., Frake, A.M., Chantawannakul, P.
(2014) Observations on the removal of brood inoculated with Tropilaelaps mercedesae (Acari: Laelapidae) and the mite's reproductive success in Apis mellifera colonies. Exp. Appl. Acarol. 62 (1), 47-55

Khongphinitbunjong, K., de Guzman, L.I., Tarver, M.R., Rinderer, T.E., Chantawannakul, P. (2015) Interactions of Tropilaelaps mercedesae, honey bee viruses and immune responses in Apis mellifera. J. Apic Res. . doi:10.1080/00218839.2015.1041311

Kirrane, M., de Guzman, L.I., Rinderer, T.E., Frake, A.M., Wagnitz, J., Whelan, P.M. (2011) Asynchronous development of honey bee host and Varroa destructor influences reproductive potential of mites. J. Econ. Entomol. 104, 1146-1152

Kitprasert, C. (1984) Biology and systematics of the parasitic mite, Tropilaelaps clareae Delfinado and Baker (Acarina: Laelapidae), M.S. Thesis, Kasetsart University, Thailand (in Thai)

Kitprasert, C. (1995) Parasitism by the brood mite, Euvarroa sinhai Delfinado and Baker (Acari: Varroidae) on the dwarf honey bee, Apis florea F. (Hymenoptera: Apidae) in Thailand. Ph.D. Dissertation. Oregon State University. pp. 1-96

Klee, J., Besana, A.M., Genersch, E., Gisder, S., Nanetti, A., et al. (2007) Widespread dispersal of the microsporadian Nosema ceranae and emergent pathogen of western honey bee, Apis mellifera. J. Invertebr. Pathol. 96, 1-10

Koeniger, N., Musaffar, N. (1988) Lifespan of the parasitic honeybee mite, Tropilaelaps clareae, on Apis cerana, A. dorsata and A. mellifera . J. Apic. Res. 27, 207-212

Koeniger, N., Koeniger, G., Delfinado-Baker, M. (1983) Observations on mites of the Asian honey bee species. Apidologie 14, 197-204

Koeniger, N., Koeniger, G., de Guzman, L.I., Lekprayoon, C. (1993) Survival of Euvarroa sinhai Delfinado and Baker (Acari, Varroidae) on workers of Apis cerana Fabr, Apis florea Fabr. and Apis mellifera L. in cages. Apidologie 24, 403-410

Koeniger, N., Koeniger, G., Mardan, M. (1994) Mimicking a honeybee queen? Vespa affinis indosinensis Pérez 1910 hunts drones of Apis cerana F. Ethology 98, $149-153$

Koeniger, N., Koeniger, G., Gries, M., Tingek, S., Kelitu, A. (1996) Observations on colony defense of Apis nuluensis and predatory behaviour of the hornet, Vespa multimaculata Pérez, 1910. Apidologie 27, 341-352

Koeniger, G., Koeniger, N., Anderson, D.L., Lekprayoon, C., Tingek, S. (2002) Mites from debris and sealed brood cells of Apis dorsata colonies in Sabah (Borneo) Malaysia, including a new haplotype of Varroa jacobsoni. Apidologie $33,15-24$

Kojima, Y., Toki, T., Morimoto, T., Yoshiyama, M., Kimura, K., Kadowaki, T. (2011) Infestation of Japanese native honey bees by tracheal mite and virus from non-native European honey bees in Japan. Microbiol. Ecol. 62 , 895-906 
Kulincevic, J.M., Rinderer, T.E., Mladjan, V.J. (1991) Effects of fluvalinate and amitraz on bee lice (BraulaCoeca Nitzsch) in honey bee (Apis mellifera L.) colonies in Yugoslavia. Apidologie 22, 43-47

Laigo, F.M., Morse, R.A. (1968) The mite Tropilaelaps clareae in Apis dorsata colonies in the Philippines. Bee World 49, 116-118

Lekprayoon, C., Tangkanasing, P. (1991) Euvarroa wongsirii, a new species of bee mite from Thailand. Internat. J. Acarol. 17, 255-258

Li, J. Qin, H., Wu, J., Sadd, B.M., Wang, X., Evans J.D., Peng W. (2012) The prevalence of parasites and pathogens in Asian honey bees Apis cerana in China. PLoS ONE 7 (11), e47955. 1-12

Liu, T.P. (1991) Virus-like particles in the tracheal mite Acarapis-woodi (Rennie). Apidologie 22, 213-219

Liu, F., Wang, Q., Dai, P.L., Wu, Y.Y., Song, H.K., Zhou, T. (2008) Natural stripe of microsporadia of honey bee in China. Chinese Bull. Entomol 45, 963-966

Lo, N., Gloag, R.S., Anderson, D.L., Oldroyd, B.P. (2010) A molecular phylogeny of the genus Apis suggests that the giant honey bee of the Philippines, A. breviligula Maa, and the plains honey bee of southern India, A. indica Fabricius, are valid species. Syst Entomol 35(2), 226-233

Maassen, A. (1913) Weitere Mitteilungen uber der seuchenhaften Brutkrankheiten der Bienen [Further communication on the epidemic brood disease of bees]. Mitteilungen aus der Kaiserlichen Biologischen Anstalt fur Land- und Forstwirtschaft 14, 48-58

Martin, S. (1998) A population model for the parasitic mite Varroa jacobsoni in honey bee (Apis mellifera) colonies. Ecol. Model. 109, 267-281

Matheson, A. (1993) World bee health report. Bee World 74, 176-212

Matheson, A. (1995) World bee health report. Bee World 76, 31-39

Maori, E., Lavi, S., Mozes-Koch, R., Gantman, Y., Peretz, Y., Edelbaum, O., Tanne, E., Sela, I. (2007) Isolation and characterization of Israeli acute paralysis virus, a Dicistrovirus affecting honeybees in Israel: evidence for diversity due to intra- and inter-species recombination. J. Gen. Virol. 88, 3428-3438

Matsuura, M. (1988) Ecological studies on vespine wasps (Hymenoptera: Vespidae) attacking honeybee colonies. Appl. Entomol. Zool. 23, 428-440

Michael, D.S. (1957) Acarine disease found in India. Am. Bee. J. 97, 107

Milne, P.S. (1957) Acarine disease in Apis indica. Bee World 38, 156

Mookhploy, W., Kimura, K., Disayathanoowat, T., Yoshiyama, M., Hondo, K. Chantawannakul, P. (2015) Capsid gene divergence of Black queen cell virus isolates in Thailand and Japan honey bee species. J. Econ. Entomol. 1-5. doi:10.1093/ jee/tov 102

Morimoto, T., Kojima, Y., Yoshiyama, M., Kimura, K., Yang, B., Kadowaki, T. (2012) Molecular identification of chronic bee paralysis virus infection in Apis mellifera colonies in Japan. Viruses 4(7), 1093-1103

Morgenthaler, O. (1934) Krankheitserregende und harmlose Artender Bienenmilbe Acarapis, zugleich ein Beitrag zum species-problem. Rev. Suisse Zool. 41, 429-446

Mossadegh, M.S. (1990) In vitro observations on ontogenesis of the mites, Euvarroa sinhai Delfinado and Baker (Acari: Varroidae), in drone brood cells of the honey bee, Apis mellifera L. J. Apic. Res. 29, 230-232

Mossadegh, M.S. (1991) Geographical distribution, levels of infestation and population density of the mite Euvarroa sinhai Delfinado and Baker (Acarina: Mesostigmata) in Apis florea F colonies in Iran. Apidologie 22, 127-134

Mossadegh, M.S., Bahreini, R. (1994) Acarapis mites of honey-bee, Apis mellifera in Iran. Exp. Appl. Acarol. 18, 503-506

Naug, D. (2009) Nutritional stress due to habitat loss may explain recent honeybee colony collapses. Biol. Con. 142, 2369-2372

Navajas, M., Anderson, D.L., de Guzman, L.I., Huang, Z.Y., Clement, J., Zhou, T., Le Conte, Y. (2010) New Asian types of Varroa destructor: a potential new threat for world apiculture. Apidologie 41, 181-193

National Bureau of Agricultural Commodity and Food Standards (2008) Diagnosis of American foulbrood in bee. National Thai Agricultural Standard TAS 10351-2007, Royal Gazette Vol. 125 Special Section 3 D, 4 January B.E.2551. 16pp

Neumann, P., Elzen, P.J. (2004) The biology of the small hive beetle (Aethina tumida, Coleoptera: Nitidulidae): Gaps in our knowledge of an invasive species. Apidologie 35, 229-247

Neumann, P., Carreck, N.L. (2010) Honey bee colony losses. J. Apic. Res. 49, 1-6

Noh, J.H., Reddy, K.E., Choe, S.E., Yoo, M.S., Doan, H.T.T., et al. (2013) Phylogenetic analysis of black queen cell virus genotypes in South Korea. Virus Genes 46 (2), 362-368

Office International des Épizooties (OIE) (2004) World Animal Health 2004. Animal health status and disease control methods. Part 2. Tables. Office International des Épizooties, Paris. France.

Oldroyd, B., Wongsiri, S. (2006) Asian Honey Bees: Biology, Conservation, and Human Interactions. Harvard University Press, London, England

Ono, M., Okada, I., Sasaki, M. (1987) Heat production by balling in the Japanese honeybee, Apis cerana japonica as a defensive behavior against the hornet, Vespa simillima xanthoptera. Experientia 43, 1031-1032

Otis, G.W. (1996) Distribution of recently recognized species of honey bees (Hymenoptera: Apidae; Apis ). J. Kans. Entomol. Soc 69 (supplement), 311-333

Otis, G.W., Kralj, J. (2001) Parasitic mites not present in North America. In: Webster, T.C., Delaplane, K.S. 
(eds.) Mites of the Honey Bee, pp. 251-272. Dadant, Hamilton, IL

Oudemans, A.C. (1904) On a new genus and species of parasitic Acari. Notes Leyden Mus. 2, 216-222

Pattamayutanon, P., Angeli, S., Thakeow, P., Abraham, J., Disayathanoowat, T., Chantawannakul, P. (2015) Biomedical activity and related volatile compounds of Thai honeys from three different honeybee species. J. Food Sci. . doi:10.1111/1750-3841.12993

Pernal, S.F., Clay, H. (2013). Honey bee diseases and pests, 3rd Edition. Canadian Association of Professional Apiculturists, Beaverlodge AB, Canada 68 pp.

Peng, Y.S., Fang, Y., Xu, S., Ge, L. (1987a) The resistance mechanism of the Asian honeybee, Apis cerana Fabr., to an ectoparasitic mite, Varroa jacobsoni Oudemans. J. Invertebr. Pathol. 49, 54-60

Peng, Y.S., Fang, Y., Xu, S., Ge, L., Nasr, M.E. (1987b) Response of foster Asian honeybee (Apis cerana Fabr.) colonies to the brood of European honeybee (Apis mellifera L.) infested with parasitic mite, Varroa jacobsoni Oudemans. J. Invertebr. Pathol. 49, 259264

Promnuan, Y., Kudo, T., Chantawannakul, P. (2009) Actinomycetes isolated from beehives in Thailand. World J. Microb. Biot. 25(9), 1685-1689

Promnuan, Y., Kudo, T., Ohkuma, M., Chantawannakul, P. (2011) Actinomadura apis sp. nov., isolated from a honey bee (Apis mellifera) hive, and the reclassification of Actinomadura cremea subsp. rifamycini Gauze et al. 1987 as Actinomadura rifamycini (Gauze et al. 1987) sp. nov., comb. nov. Int. J. Syst. Evol. Microbiol $61(9), 2271-2277$

Ra, D.K., Jeong, C., Lee, J.H., Lee, Y.M., Kim, K.H., Han, T.H., Lee, S.M. (2012) Prevalence of honeybee diseases in Incheon area in 2011. Korean J. Vet. Serv 35, $111-117$

Radloff, S.E., Hepburn, H.R., Fuchs, S., Otis, G.W., Hadisoesilo, S., Hepburn, C., Tan, K. (2005a) Multivariate morphometric analysis of the Apis cerana populations of oceanic Asia. Apidologie 36, 475-492

Radloff, S.E., Hepburn, H.R., Hepburn, C., Fuchs, S., Otis, G.W., et al. (2005b) Multivariate morphometric analysis of Apis cerana of southern mainland Asia. Apidologie 36, 127-139

Radloff, S.E., Hepburn, C., Hepburn, H.R., Fuchs, S., Hadisoesilo, S., Tan, K., Engel, M.S., Kuznetsov, V. (2010) Population structure and classification of Apis cerana . Apidologie 41, 589-601

Raffique, M.K., Mahmood, R., Aslam, M., Sarwar, G. (2012) Control of Tropilaelaps clareae mite by using formic acid and thymol in honey bee Apis mellifera L. colonies. Pakistan J. Zool. 44, $1129-1135$

Rana, B.S., Rao, K.M., Chakravarty, S.K., Katna, S. (2012) Characterization of Melisococcus plutonius causing European foulbrood disease in Apis cerana F. J. Apic. Res. 51, 306-311

Rashad, S.E., Eweis, M.A., Nour, M.E. (1985) Studies on the infestation of honeybees (Apis mellifera) by
Acarapis woodi in Egypt. Proc. 3rd Intern. Conf. Apic. Trop. Climates Nairobi. 1984, 152-156

Reddy, K.E., Noh, J.H., Kim, Y.-H., Yoo, M.S., Doan, H.T.T., et al. (2013) Analysis of the nonstructural and structural polyprotein regions, and complete genome sequences of Israel acute paralysis viruses identified from honeybees (Apis mellifera) in Korea. Virology 444 (1-2), 211-217

Rennie, J. (1921) Isle of Wight disease in hive bees - acarine disease: the organism associated with the disease-Tarsonemus woodi. N. sp. Trans. R. Soc. Edinburgh 52, 768-779

Rice, R. (2001) Nosema diseases in honeybees. Genetic variation and control RIRDC 1/46. Rural Industries Research and Development Corporation, Kingston, $36 \mathrm{pp}$.

Rinderer, T.E., Oldroyd, B.P., Lekprayoon, C., Wongsiri, S., Thapa, R. (1994) Extended survival of the parasitic mite Tropilaelaps clareae on adult workers of Apis mellifera and Apis dorsata . J. Apic. Res. 33, 171-174

Rinderer, T.E., Wongsiri, S., Kuang, B., Liu, J., Oldroyd, B., Sylvester, H.A., de Guzman, L.I. (1996) Comparative nest architecture of the dwarf honey bees. J. Apic. Res. 35, 19-26

Rinderer, T.E., Harris, J.W., Hunt, G., de Guzman, L.I. (2010) Breeding for resistance to Varroa destructor in North America. Apidologie 41, 409-424

Ritter, W., Schneider-Ritter, U. (1988) Differences in biology and means of controlling Varroa jacobsoni and Tropilaelalps clareae, two novel parasitic mites of Apis mellifera. In: Needham, G.R., Page Jr., R.E., Delfinado-Baker, M., Bowan, C.E. (eds.) Africanized honeybees and bee mites, pp. 387-395. Halsted Press, New York

Rosenkranz, P., Aumeier, P., Ziegelmann, B. (2010) Biology and control of Varroa destructor. J. Invertebr. Pathol. 103, S96-S119

Royce, L.A., Krantz, G.W., Ibay, L.A., Burgett, D.M. (1988) Some observations on the biology and behavior of Acarapis woodi and Acarapis dorsalis in Oregon. In: Needham, G.R., Page Jr., R.E., Delfinado-Baker, M., Bowan, C.E. (eds.) Africanized honeybees and bee mites, pp. 387-395. Halsted Press, New York

Ruttner, F. (1988) Biogeography and taxonomy of honey bees. Springer Verlag, Berlin. 284 pp

Sakagami, S.F., Matsumura, T., Ito, K. (1980) Apis laboriosa in Himalaya, the little known world's largest honey bee (Hymenoptera, Apidae). Insecta Matsumurana 19, 47-78

Sammataro, D. (2011) Global status of honey bee mites. In: Sammataro, D., Yoder, J.A. (eds.) Honey Bee Colony Health: Challenges and Sustainable Solutions, pp. 4158. CRC Press, Boca Raton, USA

Sanpa, S., Chantawannakul, P. (2009) Survey of six bee viruses using RT-PCR in Northern Thailand. J. Invertebr. Pathol. 100, 116-119

Sanpa, S., Popova, M., Bankova, V., Tunkasiri, T., Eitssayeam, S., Chantawannakul, P. (2015) 
Antibacterial compounds from propolis of Tetragonula laeviceps and Tetrigona melanoleuca (Hymenoptera: Apidae) from Thailand. PLoS ONE 10(5), e0126886

Saraithong, P., Li, Y., Saenphet, K., Chen, Z., Chantawannakul, P. (2015a) Bacterial community structure in Apis florea larvae analyzed by denaturing gradient gel electrophoresis and 16S rRNA gene sequencing. Insect Sci. 22, 606-618. doi:10.1111/17447917.12155

Saraithong, P., Li, Y., Saenphet, K., Chen, Z., Chantawannakul, P. (2015b) Midgut bacterial communities in the giant Asian honeybee (Apis dorsata) across four developmental stages: A comparative study. Insect Sci. doi:10.1111/1744-7917.12271, in press

Simone-Finstrom, M.D., Spivak, M. (2012) Increased Resin Collection after Parasite Challenge: A Case of SelfMedication in Honey Bees? PLoS ONE 7 (3), e34601. doi:10.1371/journal.pone. 0034601

Simone, M., Evans, J.D., Spivak, M. (2009) Resin collection and social immunity in honey bees. Evolution 63, 3016-3022

Singh, S. (1961) Appearance of American foulbrood disease in Indian honey bee (Apis indica Fabr.). Indian Bee J 23 (7/9), 46-50

Shah, F.A., Shah, T.A. (1988) Thai sacbrood disease of Apis cerana. Indian Bee J. 50, 110-112

Shimanuki, H., Calderone, N.W., Know, D.A. (1994) Parasitic mite syndrome: the symptom. Am. Bee. J. 134, 827-828

Solignac, M., Cornuet, J., Vautrin, D., Le Conte, Y., Anderson, D., Evans, J., Cros-Arteil, S., Navajas, M. (2005) The invasive Korean and Japanese types of Varroa destructor, ectoparasite mite of the Western honey bee (Apis mellifera), are two partially isolated clones. Proc. R. Soc London B 272, 411-419

Stanley, J., Sah, K., Jain, S.K., Bhatt, J.C., Sushil, S.N. (2015) Evaluation of pesticide toxicity at their field recommended doses to honeybees, Apis cerana and A. mellifera through laboratory, semi-field and field studies. Chemosphere 119, 668-674

Suwannapong, G., Yemor, T., Boonpakdee, C., Benbow, M.E. (2011) Nosema ceranae, a new parasite in Thai honeybees. J. Invertebr. Pathol. 106 (2), 236-241

Takahashi, J., Yoshida, T., Takagi, T., Akimoto, S., Woo, K.S., Deowanish, S., Hepburn, R., Nakamura, J., Matsuka, M. (2007) Geographic variation in the Japanese islands of Apis cerana japonica and in A. cerana populations bordering its geographic range. Apidologie 38, 335-340

Takamatsu, D., Morinishi, K., Arai, R., Sakamoto, A., Okura, M., Osaki, M. (2014) Typing of Melissococcus plutonius isolated from European and Japanese honey bees suggests spread of sequence types across borders and between different Apis species. Vet. Microbiol. $171,221-226$

Tan, K., Hepburn, H.R., Radloff, S.E., Yu, Y., Liu, Y., Zhou, D., Neumann, P. (2005) Heat-balling wasps by honeybees. Naturwissenschaften 92, 492-495
Tan, K., Hepburn, H.R., Radloff, S.E., Fuchs, S., Fan, X., Zhang, L., Yang, M. (2008) Multivariate morphometric analysis of the Apis cerana of China. Apidologie 39, 343-353

Tan, K., Li, H., Yang, M.X., Hepburn, H.R., Radloff, S.E. (2010) Wasp hawking induces endothermic heat production in guard bees. J. Insect Sci. 10, 1-6

Theantana, T., Chantawannakul, P. (2008) Protease and beta- $\mathrm{N}$ acetylglucosaminidase of honey bee chalkbrood pathogen Ascosphaera apis. J. Apic. Res. 47 (1), 68-76

Tingek, S., Koeniger, N., Koeniger, G. (1996) Description of a new cavity-dwelling species of Apis (Apis nuluensis) from Sabah, Borneo with notes on its occurrence and reproductive biology (Hymenoptera, Apoidea, Apini). Senckenbergiana Biol. 76, 115-119

Triyasut, P., Mookhploy, W., Kimura, K., Yoshiyama, M., Khongphinitbunjong, K., Chantawannakul, P. (2015) First detection of honey bee viruses in wax moth. Chiang Mai J. Sci., in press

Tutkun, E., Maden, S., Inci, A., Yilmarz, B. (1993) General situation of chalkbrood disease in honey bees in Turkey. Turk. Entomol. Derg. 17 (2), 65-68

van Engelsdorp, D., Meixner, M.D. (2010) A historical review of managed honey bee populations in Europe and the United States and the factors that may affect them. J Invertebr Pathol 103, S80-S95

Van der Zee, R., Pisa, L., Andonov, S., Brodschneider, R., Charrière, J.-D., et al. (2012) Managed honey bee colony losses in Canada, China, Europe, Israel and Turkey, for the winters of 2008-9 and 2009-10. J. Apic. Res. 51 (1), 100-114

Wanjai, C., Sringarm, K., Santasup, C., Pak-Uthai, S., Chantawannakul, P. (2012) Physicochemical and microbiological properties of longan, bitter bush, sunflower and litchi honeys produced by Apis mellifera in Northern Thailand. J. Apic. Res. 51, 36-44

Warrit, N., Smith, D.R., Lekprayoon, C. (2006) Genetic subpopulations of Varroa mites and their Apis cerana hosts in Thailand. Apidologie 37, 19-30

White, G.F. (1913) Sacbrood, a disease of bees. US Department of Agriculture, Bureau of Entomology, Circular No. 169

Whitaker, J., Szalanski, A.L., Kence, M. (2011) Molecular detection of Nosema ceranae and N. apis from Turkish honey bees. Apidologie 42, 174-180

Williams, G.R., Sampson, M.A., Shutler, D., Rogers, R.E.L. (2008) Does fumagillin control the recently detected invasive parasite Nosema ceranae in western honey bees (Apis mellifera)? J. Invertebr. Pathol. 99, 342-344

Williams, G.R., Shutler, D., Little, C.M., BurgherMacLellan, K.L., Rogers, R.E.L. (2011) The microsporidian Nosema ceranae, the antibiotic Fumagilin-B (R), and western honey bee (Apis mellifera) colony strength. Apidologie 42, $15-22$

Williams, G.R., Tarpy, D.R., Vanengelsdorp, D., Chauzat, M.P., Cox-Foster, D.L., Delaplane, K.S., Neumann, P., 
Pettis, J.S., Rogers, R.E.L., Shutler, D. (2010) Colony Collapse Disorder in context. Bioessays 32, 845-846

Wongsiri, S., Tangkanasing, P. (1987) Mites, pests and beekeeping with Apis cerana and Apis mellifera in Thailand. Am. Bee J. 127, 500-503

Wongsiri, S., Tangkanasing, P., Sylvester, H.A. (1989) The resistance behavior of Apis cerana against Tropilaelaps clareae, pp. 828-836. Proc. First AsiaPacific Conf. of Enotmol. Chiang Mai, Thailand

Wongsiri, S., Thapa, R., Chantawannakul, P., Chaiyawong, T., Thirakhupt, K., Meckvichai, W. (2005) Bee eating birds and honey bees predation in Thailand. Am. Bee. J. 145(5), 419-422

Woyke, J. (1984) Survival and prophylactic control of Tropilaelaps clareae infesting Apis mellifera colonies in Afghanistan. Apidologie 15, 421-434

Woyke, J. (1985) Further investigations into control of the parasite bee mite Tropilaelaps clareae without medication. J. Apic. Res. 24, 250-254

Woyke, J. (1987a) Infestation of honeybee (Apis mellifera) colonies by the parasitic mites Varroa jacobsoni and Tropilaelaps clareae in South Vietnam and results of chemical treatment. J. Apic. Res. 26, 64-67

Woyke, J. (1987b) Length of stay of the parasitic mite Tropilaelaps clareae outside sealed honeybee brood cells as basis for its effective control. J. Apic. Res. 26, 104-109

Woyke, J. (1987c) Length of successive stages in the development of the mite Tropilaelaps clareae in relation to honeybee brood age. J. Apic. Res. 26, 110-114

Wu, J., Li, J., Li, J.K. (2006) Major honey plants and their utilization in China. Am. Bee J. 2, 153-157
Yang, G.-H. (2005) Harm of introducing the western honeybee Apis mellifera $\mathrm{L}$. to the Chinese honeybee Apis cerana F. and its ecological impact. Acta Entomol. Sin. 48, 401-406

Yang, B., Peng, G., Li, T., Kadowaki, T. (2013) Molecular and phylogenetic characterization of honey bee viruses, Nosema microsporidia, protozoan parasites, and parasitic mites in China. Ecol. Evol. 3(2), 298-311

Yen, D.F., Chyn, L.C. (1971) Studies on a bacterial disease of honey bee in Taiwan. Plant Protection Bulletin 13, 12-17

Yoo, M.S., Yoon, B.S., 4 (2009) Incidence on honey bee disease in Korea 2009. Korean J. Apicul 24, 273-278

Yoshiyama, M., Kimura, K. (2011) Distribution of Nosema ceranae in the European honeybee, Apis mellifera in Japan. J. Invertebr. Pathol. 106, 263-267

Zander, E. (1909) Tierische Parasiten als Krankenheitserreger bei der Biene. Münchener Bienenzeitung 31, 196-204

Zhang, X., He, S.Y., Evans, J.D., Pettis, J.S., Yin, G.F., Chen, Y.P. (2012) New evidence that deformed wing virus and black queen cell virus are multi-host pathogens. J. Invertebr. Pathol. 109 (1), 156-159

Zhou, T., Feng, F., Dong, B. (2000) Study on the pathogen of European foulbrood in the Chinese honey bee (Apis cerana cerana F.). Acta Entomol. Sinica 43, 104-108

Zhou, T., Anderson, D., Huang, Z.S.H., Yao, J., Tan, K., Zhang, Q. (2004) Identification of Varroa mites (Acari: Varroidae) infesting Apis cerana and Apis mellifera in China. Apidologie 35, 645-654 